\title{
ESTUDO DA VEGETAÇÃO RELACIONADA COM A ALIMENTAÇÃO DO “PACU” (COLOSSOMA MITREI-BERG(1895) NO PANTANAL MATO-GROSSENSE
}

\author{
José Elias de Paula 1 \\ Manoel Batista de Morais Filho ${ }^{2}$ \\ Geraldo Bernardino ${ }^{2}$ \\ José Sávio Colares de Melo \\ Valdir Aparecido Ferrari ${ }^{2}$
}

\begin{abstract}
RESUMO: - Os 102 aparelhos digestivos analisados foram provenientes de espécimes capturados no Pantanal de Mato Grosso, nos municípios do Poconé e Barão de Melgaço. O estudo da vegetação aquática, ciliar e de áreas inundáveis foi conduzido nas áreas onde os espécimes de "pacu" foram capturados. Foram considerados também dados biométricos do "pacu", tais como: comprimento total do esôfago, do intestino e do estômago.
\end{abstract}

Palavras-chave: Colossoma mitrei, Vegetação, Alimentação, Biometria.

\begin{abstract}
This study is part of the "pacu" (Colossoma mitrei Berg 1895) project of biotecnology. The studies were conducted in areas of Pantanal, municipalities of Poconé and Barão de Melgaço (Mato Grosso, Brasil). In conjunction with the vegetation study, the stomach contents od 102 especimes of "pacu" were analized. The results indicate that Colossoma mitrei's custom feeding is herbivorous.
\end{abstract}

Key words: Colossoma mitrei, vegetation, feeding, biometry.

\section{Introdução}

Os resultados dos nossos estudos anteriores realizados sobre a vegetação aquática e ciliar, nos rios Itapecuru (Maranhão), Araguaia e Tocantins (Goiás e Pará), e no Lago Paranóa de Brasília (Paula, 1976, 1978, 1982) têm revelado que a vida da fauna aquática, notadamente da ictiofauna, é dependente direto e indiretamente da vegetação a que nos referimos. O vegetal, inclusive algas, é a fonte básica e insubstituível de alimento de um grande número de espécies de peixe, de artrópodos e moluscos. Esses e outros animais herbívoros são por sua vez a fonte alimentar dos peixes carnívoros. Peixes de ovos adesivos desovam em plantas aquáticas ou na lama das margens ou ainda nos fundos das massas líquidas (Souza 1971). Bard et al. (1974) salientam que as plantas aquáticas servem de suporte ao perifiton (algas, larvas de insetos e moluscos) e as plantas superiores servem de alimentos para os animais, inclusive para os peixes. Por outro lado, as raízes de Eichornia crassipes são fixadoras de ovos de peixes (Machado 1974).

O CERLA incluiu no seu Projeto, que tem por escopo estabelecer parâmetros biotecnológicos para criação do "pacu” em cativeiro destinado à exploração comercial, o estudo do hábito alimentar dessa espécie no seu habitat. Foi uma iniciativa acertada, tendo em vista que o sucesso a médio prazo desse Projeto depende fundamentalmente do conhecimento biológico do "pacu" no ecossistema do qual é parte integrante. Estudo da alimentação e reprodução de Colossoma mitrei em cativeiro foram realizados (Souza e Cantelo 1986; Ribeiro et al. 1986; Teodoro e Lima 1986).

1 Doutor em Ciências, biólogo, Professor de Botânica, Universidade de Brasília, IB-VEG, 70.910, Brasília-DF, bolsista do CNPq.

2 Pesq̄uisadores do Centro Regional Latino Americano de Agricultura-CERLA, 13.630, Pirassununga-SP. 
O Pantanal Matogrossense está situado entre $16^{\circ}$ e $21^{\circ}$. de Latitude Sul (S) e entre $55^{\circ}$ e $58^{\circ}$ de Longitude Oeste (W) e ocupa uma área de $120 \mathrm{mil} \mathrm{km}{ }^{2}$, a outra parte (100 mil $\mathrm{km}^{2}$ ) pertence ao Paraguai e Bolívia, estendendo-se até $22 \% \mathrm{~S}$, perfazendo um total de $220 \mathrm{mil} \mathrm{km} \mathrm{km}^{2}$. O Pantanal é uma região que ainda não sofreu os efeitos das ações predatórias do homem, com exceção de algumas áreas isoladas. É, sem dúvida, uma das últimas Reservas Ecológicas do Planeta Terra, portanto, um Patrimônio Vivo da Humanidade.

Basicamente, a Região do Pantanal consta de áreas não inundáveis, inundáveis e permanentemente inundadas. As não inundáveis são representadas por Cerrados (com árvores esparsas e tortuosas, estratos arbustivos e herbáceos) e Chaco (serras e áreas planas secas) de solo calcário, cuja vegetação é fisionômica e floristicamente semelhante a da Caatinga do Nordeste brasileiro. Dentre as espécies da Caatinga que ocorrem também no Complexo do Pantanal (partes secas calcárias), salientamos Parkinsonia aculeta L., Jatropha urens L. (cansanção), Jacaratia corumbensis Kunt. (mamãozinho), Astronium urundeuva Engl. (aroeira), Acacia farnesiana Willd., Zizyphus joazeiro Mart. (Juazeiro), Tabebuia caraiba Bur. (craibeira), Pterogyne nitens Tul. (madeira nova) e Bumelia sertorum Mart. A flora do Pantanal é uma mistura de vários tipos de vegetação de outras regiões, dai a denominação: Complexo do Pantanal. Nesse Complexo, as espécies vegetais, notadamente as aquáticas e as das áreas inundáveis, ocorrem sempre formando grandes populações.

\section{Método}

O conteúdo dos estômagos e dos intestinos foi estudado ao microscópio e estereoscópio, para tanto, utilizamos um estereoscópio binocular Spencer, um microscópio ZeissGFP binocular e um fotomicroscópio Zeiss-II binocular.

Em alguns casos foram feitos testes com solução diluída de floroglucina a fim de saber com segurança se o trato do aparelho digestivo tratava-se de fragmentos de plantas vasculares (espermatófitas e pteridófitas), pois esses dois grupos de plantas possuem lignina nas paredes celulósicas dos vasos lenhosos, das fibras e esclerócitos (Jansen, 1962). A lignina torna-se vermelho-cereja quando qualquer material lignífero, é colocado na solução de floroglucina, com gotas de ácido sulfúrico a 50\%. A identificação de caule, lâmina foliar e pecíolo, foi feita fazendo-se cortes transversais dos mesmos, posto que, os feixes vasculares na estrutura primária de dicotiledôneas estão reunidos em forma circular, no centro, delimitando medula, enquanto que nas monocotiledôneas, os feixes são difusos (distribuição atactostélica); e os feixes vasculares do pecíolo de dicotiledôneas são sempre em forma de arco.

As drusas de oxalato de cálcio foram identificadas com solução de ácido sulfúrico a 50\%: dissolvendo-as imediatamente e em seguida formando agulhas de sulfato de cálcio. A sílica, em forma de concreções, foi detectada com solução de ácido fluorídrico, na proporção de 2:1 ml, dissolvendo as concreções imediatamente.

O material botânico que comprova a identidade científica de cada espécie foi incorporado ao acervo do Herbário da Universidade de Brasília (UB), cujo número consta no final da apresentação de cada espécie.

$\mathrm{O}$ amido em forma de grãos foi identificado pela cor roxo-azulada quando submetido à solução fraca de iodo (lugol) e também com luz polarizada no microscópio: formando como efeito uma imagem escura, denominada "Cruz de Malta", representada por duas zonas escuras cruzadas.

Para a identificação de fragmentos de folha de mono e dicotiledônea, foi considerada a distribuição dos estômatos, pois, nesta, os estômatos apresentam distribuição difusa, enquanto que, naquela, os estômatos estão sempre em fileiras paralelas. 
O comprimento do aparelho digestivo foi medido após eliminadas todas as dobras, valor expresso em centímetros.

\section{Resultados}

Material proveniente do Município Barão de Melgaço (Mato Grosso) - Pantanal. Local: Baía Sinhá Mariana; manhã, data: 07/07/83 e 08/07/83.

\section{Espécimes Jovens}

N. 3 (fêmea) - Dados biométricos. Peso $800 \mathrm{~g}$; comprimento total: $31,5 \mathrm{~cm}$; comprimento do esôfago: $6,5 \mathrm{~cm}$; comprimento do estômago: $12,5 \mathrm{~cm}$; comprimento do intestino: $68,0 \mathrm{~cm}$.

Estômago cheio $(5 \mathrm{~g})$ de fragmentos de vegetal superior, tais como, pedaços de caule e de folha (Figura 2). O trato do intestino consta de fragmentos digeridos de vegetal superior e não digeridos.

N. 4 (fêmea) - Dados biométricos. Peso: $1.150 \mathrm{~g}$; comprimento total: $37,0 \mathrm{~cm}$; comprimento do esôfago; $6,5 \mathrm{~cm}$; comprimento do estômago: $13,0 \mathrm{~cm}$; comprimento do intestino: $83,0 \mathrm{~cm}$.

Conteúdo estomacal ( $4 \mathrm{~g}$ ) de fragmentos de vegetal superior com até $1 \mathrm{~cm}$ de comprimento, notadamente de folha e fruto de Pouteria (Sapotaceae, família latescente) e de caule; antenas e asas de insetos; algas (Ulothrix e Diatomáceas) raramente observadas. Intestino cheio de material digerido e semidigerido; Nematódeos e ovos de Nematódeos freqüentes.

N. 2 (fêmea) - Dados biométricos. Peso: $1.120 \mathrm{~g}$; comprimento total: $34,5 \mathrm{~cm}$; comprimento do esôfago: $6,5 \mathrm{~cm}$; comprimento do estômago: $12,5 \mathrm{~cm}$; comprimento do intestino: $70,0 \mathrm{~cm}$.

Estômago vazio, com apenas alguns fragmentos de vegetal superior. Intestino completamente cheio de pedaços de frutos, de caule e de folhas (Figura 1). Nematódeos abundantes.

N. 1 (fêmea) - Dados biométricos. Peso: $1.130 \mathrm{~g}$; comprimento total: $34,5 \mathrm{~cm}$; comprimento do esôfago: $6,0 \mathrm{~cm}$; comprimento do estômago: $12,5 \mathrm{~cm}$; comprimento do intestino: $90,0 \mathrm{~cm}$.

Estômago quase cheio $(5,3 \mathrm{~g})$ de folha, caule, um opérculo de caramujo, fragmentos de crustáceos e algumas Diatomáceas (Phractocephalus hemiliopterus) e pelos de vegetal. Intestino cheio de material digerido; Nematódeos freqüentes.

N. 1 (de 08\%07/83), fêmea. Dados biométricos. Peso: $443 \mathrm{~g}$; comprimento total: $25,8 \mathrm{~cm}$; comprimento do esôfago: $3,5 \mathrm{~cm}$; comprimento do estômago: $7,5 \mathrm{~cm}$; comprimento do intestino: $37,0 \mathrm{~cm}$.

Estômago cheio de pedaços de folha e frutos $(9 \mathrm{~g})$. Intestino com pouco material: pedaços inalterados de folha; Nematódeos escassos.

N. $2(08 / 07 / 83)$, fêmea. Dados biométricos. Peso: $820 \mathrm{~g}$; comprimento total: 31,5 $\mathrm{cm}$; comprimento do esôfago: $5,0 \mathrm{~cm}$; comprimento do estômago: $9,0 \mathrm{~cm}$; comprimento do intestino: $61,0 \mathrm{~cm}$.

Estômago com 3,5 g de fragmento de folha, sementes e caule de vegetal superior. Intestino com fragmentos de crustáceos, numerosos Nematódeos; botão floral e frutos de Gramíneas.

N. $3(08 / 07 / 83)$, fêmea. Dados biométricos. Peso: $1.850 \mathrm{~g}$; comprimento total: 40,2 $\mathrm{cm}$ : comprimento do esôfago: $6,0 \mathrm{~cm}$; comprimento do estômago: $11,0 \mathrm{~cm}$; comprimento do intestino: $114,0 \mathrm{~cm}$.

Estômago quase cheio (4 g) de fragmentos de vegetal, em fase de digestão, ocorrendo pedaços de folha, de caule, de fruto e escamas de peixe. Intestino quase vazio, com 
muitos Nematódeos.

N. $4(08 / 07 / 83)$, fêmea. Dados biométricos. Peso: $710 \mathrm{~g}$; comprimento total: 30,5 $\mathrm{cm}$; comprimento do esôfago: $4,5 \mathrm{~cm}$; comprimento do estômago: $9,0 \mathrm{~cm}$; comprimento do intestino: $36,0 \mathrm{~cm}$.

Estômago cheio (16 g) de pedaços de frutos de Dicotiledôneas e muitas sementes. Intestino cheio de fragmentos de frutos, sementes, grãos de amido e pedaços de crustáceos; drusas de oxalato de cálcio e diàtomáceas.

Baía do Mato (Rio Piraim) em 08/07/83; Hora: tarde.

\section{Espécimes jovens}

№ 1 (08/07/83), fêmea. Dados biométricos. Peso: $245 \mathrm{~g}$; comprimento total: 21,0 cm; comprimento do esôfago: $2,5 \mathrm{~cm}$; comprimento do estômago: $7,5 \mathrm{~cm}$; comprimento do intestino: $37,5 \mathrm{~cm}$.

Estômago parcialmente cheio ( $3 \mathrm{~g}$ ) de material parcialmente digerido e fragmentos de vegetal superior não digeridos e de insetos. Intestino cheio de material digerido e fragmentos de vegetal superior semidigeridos.

No. $2(08 / 07 / 83)$, fêmea. Dados biométricos. Peso: $283 \mathrm{~g}$; comprimento total: 22,5 cm; comprimento do esôfago: $2,5 \mathrm{~cm}$; comprimento do estômago: $7,0 \mathrm{~cm}$; comprimento do intestino: $43,0 \mathrm{~cm}$.

Estômago quase vazio $(2,5 \mathrm{~g})$ de pericarpo, sementes e raízes. Intestino cheio de fragmentos de planta superior, digeridos e semidigeridos, inclusive pelos, caule, fruto de Cissus (seiva incolor).

N. $3(08 / 07 / 83)$, fêmea. Dados biométricos. Peso: $554,5 \mathrm{~g}$; comprimento total: 27,0 cm; comprimento do estômago: $10,5 \mathrm{~cm}$; comprimento do intestino: $51,0 \mathrm{~cm}$; comprimento do esôfago: $4,5 \mathrm{~cm}$.

Estômago cheio $(9 \mathrm{~g})$ de frutos de Ficus. Intestino cheio de material digerido e não digerido, especialmente frutos. Ficus (Moraceae) é um gênero latescente.

N. 5 (08/07/83), macho. Dados biométricos. Peso: 453,5 g; comprimento total: 25,0 $\mathrm{cm}$; comprimento do esôfago: $4,0 \mathrm{~cm}$; comprimento do estômago: 7,0 cm; comprimento do intestino: $42,0 \mathrm{~cm}$.

Estômago cheio $(6 \mathrm{~g})$ de pedaços de até $2 \mathrm{~cm}$ de vegetal superior e fragmentos de artrópodo. Intestino com material digerido e semidigerido.

No. $6(08 / 07 / 83)$, fêmea. Dados biométricos. Peso: $406,0 \mathrm{~g}$; comprimento total: 24,0 $\mathrm{cm}$; comprimento do esôfago: $4,0 \mathrm{~cm}$; comprimento do estômago: $8,0 \mathrm{~cm}$; comprimento do intestino. $46,0 \mathrm{~cm}$.

Estômago cheio $(5,5 \mathrm{~g})$ de pedaços de folhas e caules. Intestino cheio de fragmentos de vegetal superior parcialmente digeridos, notadamente, folhas e caules; Navicula e Nematódeos.

№ 7 (08/07/83), fêmea. Dados biométricos. Peso: $397,0 \mathrm{~g}$; comprimento total: 24,7 cm; comprimento do esôfago: $4,0 \mathrm{~cm}$; comprimento do estômago: $8,5 \mathrm{~cm}$; comprimento do intestino: $40,0 \mathrm{~cm}$.

Estômago cheio $(6 \mathrm{~g})$ de fragmentos de vegetal superior em fase de digestão e íntegros. Intestino cheio de material completamente digerido.

N. 8 (08/07/83), fêmea. Dados biométricos. Peso: $408,0 \mathrm{~g}$; comprimento total: 25,0 $\mathrm{cm}$; comprimento do esôfago: $3,5 \mathrm{~cm}$; comprimento do estômago: $8,0 \mathrm{~cm}$; comprimento do intestino: $44,0 \mathrm{~cm}$.

Estômago quase vazio $(1,5 \mathrm{~g})$; fragmentos de vegetal superior escassos. Intestino cheio de fragmentos de caule, de folha e de fruto, raramente de raiz e alguns pedaços de artrópodo; Pinnunlaria major raramente observada. 
Baía Água Limpa (07/07/83).

\section{Espécimes jovens}

N. 1. Dados biométricos. Peso: $500 \mathrm{~g}$; comprimento total: $28,5 \mathrm{~cm}$; comprimento do esôfago: $4,0 \mathrm{~cm}$; comprimento do estômago; $8,0 \mathrm{~cm}$; comprimento do intestino: 50,0 $\mathrm{cm}$.

Estômago quase vazio (1,5 g); fragmentos de vegetal superior escassos. Intestino cheio de material digerido e não digerido, tais como pedaços de caule, de folha e de fruto; algas (Navicula) raramente observadas.

Cuiabá-Mirim, 07/07/83 e 08/07/83

\section{Espécimes adultos (Hora: manhã)}

N. 2. Dados biométricos. Peso: $2.100 \mathrm{~g}$; comprimento total: $42,0 \mathrm{~cm}$; comprimento do esôfago: $6,0 \mathrm{~cm}$; comprimento do intestino: 108,0 cm; comprimento do estômago: $12,0 \mathrm{~cm}$.

Estômago quase cheio $(4,5 \mathrm{~g})$ de pedaços de vegetal superior e de inseto. Intestino cheio de material digerido e fragmentos de planta superior, intactos.

N. $1(07 / 07 / 83)$. Fêmea. Dados biométricos. Peso: $5.100 \mathrm{~g}$; comprimento total: 56,6 cm; comprimento do esôfago: $7,0 \mathrm{~cm}$; comprimento do estômago: $12 \mathrm{~cm}$; comprimento do intestino: $108,0 \mathrm{~cm}$.

Estômago cheio (19 g) de pedaços de folhas de Dicotiledôneas, frutos de gramíneas, pedaços de pecíolo e muitas sementes minúsculas de Dicotiledôneas. Intestino cheio de pedaços de frutos, de folhas, peciolo, grãos de amido e sementes.

N. 3. Fêmea. Dados biométricos. Peso: $6.000 \mathrm{~g}$; comprimento total: $55,5 \mathrm{~cm}$; comprimento do esôfago: $8,0 \mathrm{~cm}$; comprimento do estômago: $16,0 \mathrm{~cm}$; comprimento do intestino: $112,0 \mathrm{~cm}$.

Estômago quase vazio $(1 \mathrm{~g})$ de folíolos de Leguminosae e outros fragmentos de plantas. Intestino cheio de material digerido e em fase de digestão, notadamente fragmentos de Dicotiledôneas e Gramíneas.

№ 4. Fêmea. Dados biométricos. Peso: $3.950 \mathrm{~g}$; comprimento total: $53,0 \mathrm{~cm}$; comprimento do esôfago: $8,0 \mathrm{~cm}$; comprimento do estômago: $16,0 \mathrm{~cm}$; comprimento do intestino: $110,0 \mathrm{~cm}$.

Estômago parcialmente cheio ( $3 \mathrm{~g})$ de fragmentos de plantas superior, especialmente ovários de Eugenia. Intestino cheio de material digerido e pedaços de folha de Gramíneas com numerosas concreções silicosas; Nematódeos freqüentes.

N. $5(08 / 07 / 83)$. Dados biométricos. Peso: $6.130 \mathrm{~g}$; comprimento total: $60,0 \mathrm{~cm}$; comprimento do esôfago: $8,5 \mathrm{~cm}$; comprimento do estômago: $17,0 \mathrm{~cm}$; comprimento do intestino: $129,0 \mathrm{~cm}$.

Estômago quase vazio $(3 \mathrm{~g})$; fragmentos de caules, folhas, pericarpos e flores. Intestino cheio de material digerido e parcialmente digerido; drusas de oxalato de cálcio freqüentes.

N. 7. Dados biométricos. Peso: $2.490 \mathrm{~g}$; comprimento total: $46,0 \mathrm{~cm}$; comprimento do esôfago: 7,0 cm; comprimento do estômago: 15,0 cm; comprimento do intestino: 107,0 $\mathrm{cm}$.

Estômago quase cheio (4 g); observados fragmentos de planta superior, inclusive folíolos de Leguminosae, provavelmente Arachis (um tipo de amendoim). Intestino cheio de material digerido, inclusive flor e folha de Echinodorus (latescente).

N. 8. Dados biométricos. Peso: $1.800 \mathrm{~g}$; comprimento total: $40,0 \mathrm{~cm}$; comprimento do esôfago: $6,0 \mathrm{~cm}$; comprimento do estômago: $11,0 \mathrm{~cm}$; comprimento do intestino: 104,0 $\mathrm{cm}$. 
Estômago parcialmente cheio $(3 \mathrm{~g})$ de fragmentos de planta superior e algumas Diatomáceas. Intestino com material digerido e pedaços de plantas inalterados.

No. 9. Fêmea. Dados biométricos. Peso: $3.550 \mathrm{~g}$; comprimento total: $52,0 \mathrm{~cm}$; comprimento do esôfago: $8,0 \mathrm{~cm}$; comprimento do estômago: $16,0 \mathrm{~cm}$; comprimento do intestino: $108,0 \mathrm{~cm}$.

Estômago parcialmente cheio $(2,5 \mathrm{~g})$ de pedaços de planta superior, notadamente folha e caule. Intestino cheio de material digerido e semidigerido; Nematódeos freqüentes.

N. 10 (10/07/83). Dados biométricos. Peso: $3.520 \mathrm{~g}$; comprimento total: $50,0 \mathrm{~cm}$; comprimento do esôfago: $8,0 \mathrm{~cm}$; comprimento do estômago: $7,0 \mathrm{~cm}$; comprimento do intestino: $132,0 \mathrm{~cm}$.

Estômago com $4 \mathrm{~g}$ de fragmentos de folhas e pecíolo e de crustáceos. Intestino com fragmentos de epiderme de dicotiledôneas, folhas de Myrtaceae, pelos, drusas de oxalato de cálcio e numerosos Nematódeos.

Boca acima do Pigueri

\section{Espécimes jovens}

№ i $(02 / 07 / 83)$. Dados biométricos. Peso: $751,0 \mathrm{~g}$; comprimento total: $32,0 \mathrm{~cm}$; comprimento do esôfago: $6,0 \mathrm{~cm}$; comprimento do estômago: $11,4 \mathrm{~cm}$; comprimento do intestino: $65,0 \mathrm{~cm}$.

Estômago cheio $(5 \mathrm{~g})$ de fragmentos de folhas. Intestino cheio de material digerido e drusas de oxalato de cálcio.

N. $2(03 / 07 / 83)$. Dados biométricos: Peso: $428,0 \mathrm{~g}$; comprimento total: $25,5 \mathrm{~cm}$; comprimento do esôfago: $6,0 \mathrm{~cm}$; comprimento do estômago: $11,3 \mathrm{~cm}$; comprimento do intestino: $61,0 \mathrm{~cm}$.

Estômago com 3,2 g de fragmentos de planta superior, tais como pedaços de caule e material no início da digestão. Intestino cheio de fragmentos de planta superior, especialmente fibras, elementos de vasos espiralados, pedaços de caule, de folhas, pelos e epiderme de Dicotiledôneas com estômatos (Figura 3).

N. $3(02 / 07 / 84)$. Dados biométricos. Peso: $436,0 \mathrm{~g}$; comprimento total: $26,0 \mathrm{~cm}$; comprimento do esôfago: $6,6 \mathrm{~cm}$; comprimento do estômago: $11,3 \mathrm{~cm}$; comprimento do intestino: $68,0 \mathrm{~cm}$.

Estômago quase vazio $(2 \mathrm{~g})$ de frutos, sementes, folhas e caules. Intestino cheio de material digerido, semidigerido e intacto, notadamente pedaços de folhas, elementos de vasos espiralados e grão de amido e ráfides (agulhas) de oxalato de cálcio (Figura 7).

N. 4. Dados biométricos. Peso: $586,0 \mathrm{~g}$; comprimento total: $30,0 \mathrm{~cm}$; comprimento do esôfago: 7,0 cm; comprimento do estômago: $13,3 \mathrm{~cm}$; comprimento do intestino: 64,0 $\mathrm{cm}$.

Estômago cheio $(5 \mathrm{~g})$ de fragmentos de vegetal superior, notadamente folha e caule. Intestino com material digerido e numerosos pedaços de planta superior não digerido. Nematódeos abundantes.

N. $5(08 / 07 / 83)$. Dados biométricos. Peso: $448,0 \mathrm{~g}$; comprimento total: $27,5 \mathrm{~cm}$; comprimento do esôfago: $5,5 \mathrm{~cm}$; comprimento do estômago $10,4 \mathrm{~cm}$; comprimento do intestino: $65,0 \mathrm{~cm}$.

Estômago cheio $(5,5 \mathrm{~g})$ de fragmentos de folhas de caules, ovários e flores. Intestino cheio de material semidigerido, pedaços de folhas, íntegros; fragmentos de vegetal com concreções siliciosas; antenas de artrópodo; Nematódeos; Ulothrix e Chironomidae.

N. 6 (02/07/83). Macho. Dados biométricos. Peso: 433,0 g; comprimento total: 27,0 $\mathrm{cm}$; comprimento do esôfago: $5,5 \mathrm{~cm}$; comprimento do estômago: 10,4 cm; comprimento do intestino; $54,0 \mathrm{~cm}$. 
Estômago quase vazio $(1,5 \mathrm{~g})$ de fragmentos de flores. Intestino com material semidigerido e completamente digerido, Diatomáceas e pelos vegetais.

№ 7 (02/07/83). Fêmea. Dados biométricos. Peso: 424,0 g; comprimento total: 25,0 cm; comprimento do esôfago: $5,5 \mathrm{~cm}$; comprimento do estômago: 10,6 cm; comprimento do intestino: $66,0 \mathrm{~cm}$.

Estômago completamente cheio (7,5 g) de fragmentos de planta superior, especialmente de folha e pedaços de crustáceos. Intestino cheio de material digerido e em fase de digestão.

№ $8(02 / 07 / 83)$. Dados biométricos. Peso: $418,0 \mathrm{~g}$; comprimento total: $26,0 \mathrm{~cm}$; comprimento do esôfago: $5,5 \mathrm{~cm}$; comprimento do estômago: $10,5 \mathrm{~cm}$; comprimento do intestino: $52,0 \mathrm{~cm}$.

Estômago cheio $(5 \mathrm{~g})$ de pedaços de frutos jovens e ovários. Intestino cheio de material digerido e não digerido (elementos de vasos espiralados e pelos).

N. $9(02 / 07 / 83)$. Macho. Dados biométricos. Peso: $552,0 \mathrm{~g}$; comprimento total: 28,8 cm; comprimento do esôfago: $7,0 \mathrm{~cm}$; comprimento do estômago; $14,0 \mathrm{~cm}$; comprimento do intestino: $48,0 \mathrm{~cm}$.

Estômago com $3 \mathrm{~g}$ de pedaços de folhas, de pecíolo, caules e frutos. Intestino cheio de pedaços de crustáceo e grãos de amido (Figuras 7, 9).

N. 10 (02/07/83). Dados biométricos. Peso: $620,0 \mathrm{~g}$; comprimento total: $29,0 \mathrm{~cm}$; comprimento do esôfago: $65,0 \mathrm{~cm}$; comprimento do estômago: $13,8 \mathrm{~cm}$; comprimento do intestino: $71,0 \mathrm{~cm}$.

Estômago cheio $(17 \mathrm{~g})$ de pedaços de folhas e frutos de Dicotiledôneas. Intestino cheio de fragmentos de folhas, de crustáceos, grãos de amido e material digerido; Nematódeos freqüentes.

Três Irmãos

\section{Espécimes jovens (coricho)}

№ $1(03 / 07 / 83)$. Dados biométricos. Peso: $550,0 \mathrm{~g}$; comprimento total: $30,0 \mathrm{~cm}$; comprimento do esôfago: $5,5 \mathrm{~cm}$; comprimento do estômago: $10,4 \mathrm{~cm}$; comprimento do intestino: $62,0 \mathrm{~cm}$.

Estômago cheio $(8,5 \mathrm{~g})$ de frutos, sementes e ovários de "tarumã" (Vitex cymosa). Intestino cheio de material digerido; Ulothrix, grãos de amido e ráfides.

.N. $4(03 / 07 / 83)$. Dados biométricos. Peso: 520,0 g; comprimento total: $30,0 \mathrm{~cm}$; comprimento do esôfago: $3,0 \mathrm{~cm}$; comprimento do estômago: $9,5 \mathrm{~cm}$; comprimento do intestino: $51,0 \mathrm{~cm}$.

Estômago cheio $(6 \mathrm{~g})$ de pedaços de folhas, caules e sementes. Intestino cheio de fragmentos de vegetal superior, digerido e não digeridos; Chironomidae, antenas de artrópodos e numerosos Nematódeos.

N. $5(03 / 07 / 83)$. Dados biométricos. Peso: $570,0 \mathrm{~g}$; comprimento total: $28,0 \mathrm{~cm}$; comprimento do esôfago: $4,5 \mathrm{~cm}$; comprimento do estômago: $10,0 \mathrm{~cm}$; comprimento do intestino: $48,0 \mathrm{~cm}$.

Estômago cheio $(6 \mathrm{~g})$ de fragmentos de folhas de Dicotiledôneas, escamas de peixe e pedaços de pecíolo e de crustáceo. Intestino com pedaços de folhas de Monocotiledôneas, antenas de artrópodos; Ulothrix, Nematódeos e Desmidium sp.

N. $6(03 / 07 / 83)$. Dados biométricos. Peso: $560,0 \mathrm{~g}$; comprimento total: $28,0 \mathrm{~cm}$; comprimento do esôfago: $5,5 \mathrm{~cm}$; comprimento do estômago: $10,4 \mathrm{~cm}$; comprimento do intestino: $48,0 \mathrm{~cm}$.

Estômago quase cheio $(3 \mathrm{~g})$ de pedaços de planta superior, notadamente de pericarpo de Ficus, Brosimum e de Eugenia, caule, folha e escamas de peixe e grãos de amido. 
Intestino cheio de material digerido e em fase de digestão e sementes com endosperma, grãos de amido e,concreções silicosas. Brosimum ((Moraceae) é um gênero latescente.

N. 7. Fêmea. Dados biométricos. Peso: $520,0 \mathrm{~g}$; comprimento total: $27,5 \mathrm{~cm}$; comprimento do esôfago: $5,5 \mathrm{~cm}$; comprimento do estômago: $10,4 \mathrm{~cm}$; comprimento do intestino, $48,0 \mathrm{~cm}$.

Estômago parcialmente cheio $(3 \mathrm{~g})$ de fragmentos de vegetal superior, especialmente de frutos jovens de Leguminosae, de Ficus e de Eugenia, e escamas de peixe. Intestino cheio de material digerido e pedaços de crustáceo, escamas de peixe e fragmentos de vegetal superior, inalterados.

N. $8(03 / 07 / 83)$. Fêmea. Dados biométricos. Peso: $540,0 \mathrm{~g}$; comprimento total: 28,0 $\mathrm{cm}$; comprimento do esôfago: $5,5 \mathrm{~cm}$; comprimento do estômago: 10,5 cm; comprimento do intestino: $59,0 \mathrm{~cm}$.

Estômago cheio $(9 \mathrm{~g})$ de fragmentos de frutos e escamas escudiformes. Intestino cheio de material digerido; fibras, Nematódeos e drusas de oxalato de cálcio.

N. $9(03 / 07 / 83)$. Fêmea. Dados biométricos. Peso: $1.350,0 \mathrm{~g}$; comprimento total: $38,0 \mathrm{~cm}$; comprimento do esôfago: $6,0 \mathrm{~cm}$; comprimento do estômago: $11.4 \mathrm{~cm}$; comprimento do intestino: $81,0 \mathrm{~cm}$.

Estômago cheio $(5,6 \mathrm{~g})$ de fragmentos de vegetal superior, notadamente pedaços de folhas com drusas de oxalato de cálcio e concreções silicosas, grãos de amido e ovos de Nematódeos. Intestino cheio de material digerido e fragmentos de planta superior, inalterados, inclusive grãos de amido e alguns caramujos, provavelmente Biomphalaria.

N. $10(03 / 07 / 83)$. Fêmea. Dados biométricos. Peso: $600,0 \mathrm{~g}$; comprimento total: $30,0 \mathrm{~cm}$; comprimento do esôfago; $5,5 \mathrm{~cm}$; comprimento do estômago: $11,0 \mathrm{~cm}$; comprimento do intestino: $70,0 \mathrm{~cm}$.

Estômago cheio $(6 \mathrm{~g})$ de pedaços de folha de Dicotiledônea, ovários, caules e patas pequenas de crustáceo. Intestino cheio de material digerido; Nematódeos freqüentes.

\section{Rio Cuiabá}

\section{Espécimes Adultos}

№ $3(07 / 07 / 83)$. Fêmea. Dados biométricos. Peso: $4.100 \mathrm{~g}$; comprimento total: 52,5 $\mathrm{cm}$; comprimento do esôfago: $8,0 \mathrm{~cm}$; comprimento do estômago: $14,4 \mathrm{~cm}$; comprimento do intestino: $122,0 \mathrm{~cm}$.

Estômago cheio de pedaços de folhas de Dicotiledôneas (sarã) e de caule. Intestino cheio de fragmentos de vegetal digeridos e não digeridos; Diatomáceas e pêlos.

N. 1. Fêmea. Dados biométricos. Peso. $3.350 \mathrm{~g}$; comprimento total: $51,0 \mathrm{~cm}$; comprimento do esôfago: $7,0 \mathrm{~cm}$; comprimento do intestino: $81,6 \mathrm{~cm}$; comprimento do estômago: $12,6 \mathrm{~cm}$.

Estômago com 2,5 g de pedaços de folhas, de flores e de caules de Dicotiledôneas. Intestino cheio de fragmentos digeridos e não digeridos de Monocotiledôneas, especialmente folhas de gramineas ((Figura 5).

№ 2. Macho. Dados biométricos. Peso: $3.850 \mathrm{~g}$; comprimento total: $54,5 \mathrm{~cm}$; comprimento do esôfago: $75 \mathrm{~cm}$; comprimento do estômago: $12,8 \mathrm{~cm}$; comprimento do intestino: $110 \mathrm{~cm}$.

Estômago cheio $(4,5 \mathrm{~g})$ de pedaços de folhas, flores (inclusive estigmas) e de frutos. Intestino cheio de fragmentos de vegetais parcialmente digeridos; Nematódeos freqüentes.

N. 5. Fêmea. Dados biométricos. Peso: $5.300 \mathrm{~g}$; comprimento total: $58,0 \mathrm{~cm}$; comprimento do esôfago: $8,5 \mathrm{~cm}$; comprimento do estômago: $14,6 \mathrm{~cm}$; comprimento do intestino: $115,0 \mathrm{~cm}$. 
O estômago estava aberto (cortado), vazio portanto. Intestino cheio de fragmentos de caule e pericarpos e esclerócitos não digeridos (Figura 8).

N. 5. Fêmea. Dados biométricos. Peso: $4.000 \mathrm{~g}$; comprimento total: $54,0 \mathrm{~cm}$; comprimento do esôfago 14;6 cm; comprimento do intestino: $12,0 \mathrm{~cm}$.

Estômago quase vazio ( $2 \mathrm{~g}$ ) de pedaços de gramíneas, de folha de Ficus; escamas de peixe em forma de escudo e Nematódeos. Intestino cheio de pelos vegetais e pedaços intactos de folhas.

№ 3. Fêmea. Dados biométricos. Peso: $4.100 \mathrm{~g}$; comprimento total: $52,5 \mathrm{~cm}$; comprimento do esôfago: $8,0 \mathrm{~cm}$; comprimento do estômago: $14,4 \mathrm{~cm}$; comprimento do intestino: $122,0 \mathrm{~cm}$.

Estômago com $3 \mathrm{~g}$ de fragmentos de planta superior (pedaços de folhas e frutos). Intestino cheio de fragmentos de folhas, de flores, de frutos, grãos de amido e ráfides de oxalato de cálcio.

N. 6. Fêmea. Dados biométricos. Peso: $3.100 \mathrm{~g}$; comprimento total: $48,0 \mathrm{~cm}$; comprimento do esôfago: $6,0 \mathrm{~cm}$; comprimento do estômago: $11,0 \mathrm{~cm}$; comprimento do intestino: $92,0 \mathrm{~cm}$.

Estômago com $3 \mathrm{~g}$ de fragmentos de folha e de flor. Intestino quase cheio; Nematódeos abundantes.

Bacia acima do Piquiri

\section{Espécimes Adultos}

№ $1(01 / 07 / 83)$. Dados biométricos. Peso: $139,6 \mathrm{~g}$; comprimento total: $42,0 \mathrm{~cm}$; comprimento do esôfago: $8,0 \mathrm{~cm}$; comprimento do estômago: $14,4 \mathrm{~cm}$; comprimento do intestino: $72,0 \mathrm{~cm}$.

Estômago completamente cheio $(9 \mathrm{~g})$ de pedaços de caules de Monocotiledôneas (semidigeridos). Intestino cheio de material parcialmente digerido e pedaços de folhas de Gramíneas não digeridos, elementos de vasos espiralados, pelos, fragmentos de caules de Gramíneas e Cotilédone (Figura 10). manhã.

Material procedente de Porto Jofre. Local Três Irmãos - Data: 12/04/84, hora:

\section{Espécimes adultos •}

No 1. Fêmea, estágio II. Dados biométricos. Peso: $3,560 \mathrm{~kg}$; comprimento total: 50,0 $\mathrm{cm}$; comprimento do esôfago: $4,0 \mathrm{~cm}$; comprimento do estômago: $12,0 \mathrm{~cm}$; comprimento do intestino: $136,0 \mathrm{~cm}$.

Estômago quase vazio (4 g) de pedaços de crustáceo, uma semente de Inga, pedaços de caule e de folha de Monocotiledônea com estômatos e Dicotiledônea. Intestino completamente cheio de fragmentos de vegetal superior, tais como, esclerócitos, sementes de Inga, digeridos e não digeridos; fragmentos de crustáceo também foram observados.

№ 2. Fêmea II. Dados biométricos. Peso 3,750 kg; comprimento total: $51,0 \mathrm{~cm}$; comprimento do esôfago: $3,9 \mathrm{~cm}$; comprimento do estômago: $17,8 \mathrm{~cm}$; comprimento do intestino: $146,0 \mathrm{~cm}$.

Estômago completamente cheio (32 g) de epiderme, pedaços de folha de Dicotiledônea e de Graminea, pedaços de caule de pecíolo, fibras e grãos de amido. Parte desses fragmentos estava completamente inteiro. Intestino cheio de material digerido, semidigerido e intactos, tais como braquiesclerócitos e macroesclerócitos, pedaços de pericarpo, fibras e sementes de Phthirusa (Loranthaceae) e folha de Sarcostemma (Asclepiadácea latescente). 
№ 3. Fêmea II. Dados biométricos. Peso: $3,200 \mathrm{~kg}$; comprimento total: $49,0 \mathrm{~cm}$; comprimento do esôfago: $2,7 \mathrm{~cm}$; comprimento do estômago: $17,2 \mathrm{~cm}$; comprimento do intestino: $130,0 \mathrm{~cm}$.

Estômago cheio ( $31 \mathrm{~g}$ ) de sementes de Eugenia (roncador), pedaços de folha e de caule e caroço de Byrsonima. Intestino completamente cheio de material digerido e não digerido, inclusive esclerócitos; Nematódeos abundantes.

No 4. Fêmea II. Dados biométricos. Peso: $4,0 \mathrm{~kg}$; comprimento total: $57,0 \mathrm{~cm}$; comprimento do esôfago: 5,2 cm; comprimento do estômago: 19,0 cm; comprimento do intestino: $141,0 \mathrm{~cm}$.

Estômago cheio ( $28 \mathrm{~g}$ ) de sementes de Paullinia (Sapindaceae), frutos de Ficus, pedaços de folha e de caule. Intestino quase vazio.

N. 5. Fêmea III. Dados biométricos. Peso: $3,400 \mathrm{~kg}$; comprimento total: 54,0 $\mathrm{cm}$; comprimento do esôfago; $3,5 \mathrm{~cm}$; comprimento do estômago: 18,4 cm; comprimento do intestino: $143,0 \mathrm{~cm}$.

Estômago quase cheio (9,5 g) de material digerido, semidigerido e não digerido, especialmente pedaços de folha e de caule, Ulothrix, Onychonema; ovos de Nematódeo. Intestino cheio de folha de Monocotiledônea, de caule de Dicotiledônea, grãos de pólen e algas.

N. 6. Fêmea II. Dados biométricos. Peso $3,700 \mathrm{~kg}$; comprimento total: $54,0 \mathrm{~cm}$; comprimento do esôfago: $5,0 \mathrm{~cm}$; comprimento do estômago: $17,5 \mathrm{~cm}$; comprimento do intestino: $130,0 \mathrm{~cm}$.

Estômago completamente cheio $(21 \mathrm{~g})$ de material digerido e não digerido (folha de Monocotiledônea e pedaços de caule). Intestino vazio.

N. 7. Macho I. Dados biométricos. Peso: $2,400 \mathrm{~kg}$; comprimento total: $47,0 \mathrm{~cm}$; comprimento do esôfago: $2,9 \mathrm{~cm}$; comprimento do estômago: $15,8 \mathrm{~cm}$; comprimento do intestino: $125,0 \mathrm{~cm}$.

Estômago cheio $(17,5 \mathrm{~g})$ de frutos de Eugenia e sementes. Intestino cheio de fragmentos digeridos e não digeridos; grãos de amido e concreções silicosas (Figura 10).

\section{Três Irmãos (13/04/84) — Hora: Manhã}

\section{Espécimes adultos}

№ 8. Macho II. Dados biométricos. Peso: $3,660 \mathrm{~kg}$; comprimento total: $51,8 \mathrm{~cm}$; comprimento do esôfago: $3,5 \mathrm{~cm}$; comprimento do estômago: $16,5 \mathrm{~cm}$; comprimento do intestino: $136,0 \mathrm{~cm}$.

Estômago quase cheio $(12 \mathrm{~g})$ de pedaços de raiz, de folha, epiderme de fruto. Intestino cheio de material digerido; grãos de pólen e algas (Anabaena, Ulothrix, Scenodesmus e Planckosphaeria.

N. 9. Fêmea III. Dados biométricos. Peso: $3,700 \mathrm{~kg}$; comprimento total: $53,2 \mathrm{~cm}$; comprimento do esôfago: $3,8 \mathrm{~cm}$; comprimento do estômago: $17,0 \mathrm{~cm}$; comprimento do intestino: $144,0 \mathrm{~cm}$.

Estômago com $8 \mathrm{~g}$ de pedaços de cotilédone de Inga e de caule, caroço de "tucum" (Baetris). Intestino quase vazio: três caroços de "tucum" foram encontrados.

N. 10. Fêmea III. Dados biométricos. Peso: $4,0 \mathrm{~kg}$; comprimento total: $55,5 \mathrm{~cm}$; comprimento do esôfago: $3,4 \mathrm{~cm}$; comprimento do estômago: $23,0 \mathrm{~cm}$; comprimento do intestino: $164,0 \mathrm{~cm}$.

Estômago quase vazio $(10 \mathrm{~g})$ de material semidigerido. Intestino completamente cheio de frutos de Phthirusa, Paullinia e Byrsonima.

N. 11. Macho II. Dados biométricos. Peso: 3,500 kg; comprimento total: $49,3 \mathrm{~cm}$; comprimento do esôfago: $3,4 \mathrm{~cm}$; comprimento do estômago: $18,3 \mathrm{~cm}$; comprimento do intestino: $136,0 \mathrm{~cm}$. 
Estômago cheio ( $25 \mathrm{~g}$ ) de fragmentos de folha de Mikania (Compositae), epiderme de folha com estômatos, pedaços de caule. Intestino cheio de material igual ao observado no estômago.

No 12. Fêmea I. Dados biométricos. Peso: $3,600 \mathrm{~kg}$; comprimento total: $49,5 \mathrm{~cm}$; comprimento do esôfago: $3,8 \mathrm{~cm}$; comprimento do estômago: $22,0 \mathrm{~cm}$; comprimento do intestino: $132,0 \mathrm{~cm}$.

Estômago cheio (60 g) de sementes de Inga, de Paullinia, de Alchornea (sarã) e de Eugênia (roncador), pedaços de folha de Gramínea, de caule; concreções silicosas de Gramínea; e grãos de amido. Intestino quase cheio de material digerido e não digerido Alchornea é Euphorbiaceae (familia latescente).

N. 13. Fêmea II. Dados biométricos. Peso: $3,600 \mathrm{~kg}$; comprimento total: $49,0 \mathrm{~cm}$; comprimento esôfago: $4,0 \mathrm{~cm}$; comprimento do estômago: $18,6 \mathrm{~cm}$; comprimento do intestino: $124,0 \mathrm{~cm}$.

Estômago cheio ( $24 \mathrm{~g}$ ) de pedaços de cotilédone, de folha e patas de crustáceo. Intestino cheio de pedaços de cotilédones, de caule e de folha e grãos de pólen.

Rio Cuiabá (Acima da união de Três Irmãos)

Data - 14/04/84, hora: manhã.

No 14. Fêmea II - Dados biométricos. Peso: $3,700 \mathrm{~kg}$; comprimento total: 53,5 $\mathrm{cm}$; comprimento do esôfago; $3,8 \mathrm{~cm}$; comprimento do estômago: $17,2 \mathrm{~cm}$; comprimento do intestino: $124,0 \mathrm{~cm}$.

Estômago cheio $(17 \mathrm{~g})$ de raiz de planta aquática flutuante, escamas de peixe. Intestino cheio de material igual ao observado no estômago.

N. 15. Macho II. Dados biométricos. Peso: $3,580 \mathrm{~kg}$; comprimento total: $50,8 \mathrm{~cm}$; comprimento do esôfago: $3,5 \mathrm{~cm}$; comprimento do estômago: $18,5 \mathrm{~cm}$; comprimento do intestino: $116,0 \mathrm{~cm}$.

Estômago cheio $(14 \mathrm{~g})$ de material digeridio e pedaços de folha, de caule e crustáceo. Intestino cheio de material digerido e inteiro, inclusive patas de crustáceo, pedaços de caule e planta superior e esclerócitos.

№ 16. Fêmea II. Dados biométricos. Peso: $3,560 \mathrm{~kg}$; comprimento total: 50,0 $\mathrm{cm}$; comprimento do esôfago: $3,2 \mathrm{~cm}$; comprimento do estômago: $18,5 \mathrm{~cm}$; comprımento do intestino: $124,0 \mathrm{~cm}$.

Estômago cheio ( $38 \mathrm{~g}$ ) de pedaços de folha de Compositae e de Ipomoea (Convolvulaceae). Intestino cheio de material digerido e não digerido, inclusive pedaços de caule e grãos de pólen de Compositae.

No 17. Fêmea II. Dados biométricos. Peso: $4,300 \mathrm{~kg}$; comprimento total: 55,0 $\mathrm{cm}$; comprimento do esôfago: $4,4 \mathrm{~cm}$; comprimento do estômago: $26,5 \mathrm{~cm}$; comprimento do intestino: $200,0 \mathrm{~cm}$.

Estômago cheio (33 g) de crustáceos quase inteiros. Intestino cheio de fragmentos de crustáceos, sementes pequenas, de cor bem escura, flores e folhas de Neptunia.

N. 18. Macho II. - Dados biométricos. Peso: $4,300 \mathrm{~kg}$; comprimento total: 48,0 $\mathrm{cm}$; comprimento do esôfago: $2,7 \mathrm{~cm}$; comprimento do estomago: $19,0 \mathrm{~cm}$; comprimento do intestino: $150,0 \mathrm{~cm}$.

Estômago quase cheio $(10 \mathrm{~g})$ de pedaços de crustáceos. Intestino cheio de pedaços de caule e de folha completamente inteiros; grãos de amido freqüentes.

N. 19. Fêmea II. Dados biométricos. peso: $2,400 \mathrm{~kg}$; comprimento total: $47,0 \mathrm{~cm}$; comprimento do esôfago: $2,5 \mathrm{~cm}$; comprimento do estômago: $19,7 \mathrm{~cm}$; comprimento do intestino: $121,0 \mathrm{~cm}$.

Estômago cheio $(36 \mathrm{~g})$ de pedaços de folha de Compositae, de Ipomoea e de Celtis (sarã-de-espinho). Intestino cheio de material digerido e Nematódeos. Ipomoea (Convolculaceae) é um gênero latescente. 
№ 20. Fêmea II. Dados biométricos. Peso: $1,950 \mathrm{~kg}$; comprimento total: $42,0 \mathrm{~cm}$; comprimento do esôfago: $2,8 \mathrm{~cm}$; comprimento do estômago: $17,5 \mathrm{~cm}$; comprimento do intestino: $119,0 \mathrm{~cm}$.

Estômago cheio ( $29 \mathrm{~g}$ ) de pedaços de frutos, inclusive de Cucurbitaceae, fragmentos de folha, de caule e grãos de amido. Intestino cheio de material digerido e não digerido (pedaços de frutos. sementes. esclerócitos): Nematódeos freqüentes.

N. 21. Macho II. Dados biométricos. Peso: $2,400 \mathrm{~kg}$; comprimento total: $45,8 \mathrm{~cm}$; comprimento do esôfago: $3,2 \mathrm{~cm}$; comprimento do estômago: $14,9 \mathrm{~cm}$; comprimento do intestino: $119,0 \mathrm{~cm}$.

Estômago com $8 \mathrm{~g}$ de sementes, caule, folha e Nematódeos. Intestino cheio de frutos de "tucum".

№ 22. Macho II. Dados biométricos. Peso: $3,500 \mathrm{~kg}$; comprimento total: $49,3 \mathrm{~cm}$; comprimento do esôfago: $3,8 \mathrm{~cm}$; comprimento do estômago: $23,0 \mathrm{~cm}$; comprimento do intestino: $114,0 \mathrm{~cm}$.

Estômago cheio ( $48 \mathrm{~g}$ ) de frutos inteiros de Byrsonima e de Eugenia. Intestino cheio de caroços de Spondias lutea (cajá), com $5 \times 2 \mathrm{~cm}$, pedaços de frutos de Byrsonima.

N. 23. Macho II. Dados biométricos. comprimento total: $48,5 \mathrm{~cm}$; comprimento do esôfago; $3,4 \mathrm{~cm}$, comprimento do estômago: 19,3 cm; comprimento do intestino: 128,0 $\mathrm{cm}$.

Estômago cheio $(37 \mathrm{~g})$ de material semidigerido e inteiro, inclusive sementes pequenas, pedaços de pericarpo, de folha e de caule. Intestino cheio de sementes de Myrtaceae e de Phthirusa, pedaços de caule, de fruto e de crustáceo.

N. 24. Macho II. Dados biométricos. Peso: $2,400 \mathrm{~kg}$; comprimento total: $45,2 \mathrm{~cm}$; comprimento do esôfago: $2,8 \mathrm{~cm}$; comprimento do estômago: 20,9 cm; comprimento do intestino: $117,0 \mathrm{~cm}$.

Estômago cheio ( $20 \mathrm{~g}$ ) de sementes de Myrtaceae, de fragmentos de caule e de folha. Intestino com Nematódeos e esclerócitos abundantes.

N. 25. Macho II. Dados biométricos. Peso: $2,560 \mathrm{~kg}$; comprimento total: $51,0 \mathrm{~cm}$; comprimento do esôfago: $2,3 \mathrm{~cm}$; comprimento do estômago: $20,1 \mathrm{~cm}$; comprimento do intestino: $131,0 \mathrm{~cm}$.

Estômago cheio $(48,5 \mathrm{~g})$ de folhas de Compositae, de Ipomoea e de Celtis. Intestino cheio de material digerido e Nematódeos.

№ 26. Fêmea II. Dados biométricos. Peso: $3,800 \mathrm{~kg}$; comprimento total: $51,0 \mathrm{~cm}$; comprimento do esôfago: $3,5 \mathrm{~cm}$; comprimento do estômago: $20,8 \mathrm{~cm}$; comprimento do intestino: $139,0 \mathrm{~cm}$.

Estômago cheio $(30 \mathrm{~g})$ de pedaços de folha, de caule, frutos de Psittacanthus. Intestino quase vazio.

Data: 15/04/84, hora: manhã.

N. 27. Macho III/IV. Dados biométricos. Peso: $3,500 \mathrm{~kg}$; comprimento total: 50,5 cm; comprimento do esôfago: $4,3 \mathrm{~cm}$; comprimento do estômago: 19,8; comprimento do intestino: $112,0 \mathrm{~cm}$.

Estômago quase vazio ( $3 \mathrm{~g}$ ) de fragmentos de caule, de folha e patas de crustáceo. Intestino quase vazio.

N. 28. Fêmea II. Dados biométricos. Peso: $2,400 \mathrm{~kg}$; comprimento total: $47,5 \mathrm{~cm}$; comprimento do esôfago: 4,0 cm; comprimento do estômago: 19,0 cm; comprimento do intestino: $136,0 \mathrm{~cm}$.

Estômago quase vazio $(3,5 \mathrm{~g})$ de pedaços de folhas e sementes. Intestino cheio de pedaços de caule e de folha; algas abundantes (Onychonema); Nematódeos freqüentes.

N. 29. Fêmea II. Dados biométricos. Peso: $2,400 \mathrm{~kg}$; comprimento total: $47,2 \mathrm{~cm}$; comprimento do esôfago: $3,4 \mathrm{~cm}$; comprimento do estômago: $27,4 \mathrm{~cm}$; comprimento do intestino: $130,0 \mathrm{~cm}$. 
Estômago completamente cheio (120 g) de frutos globos os de Byrsonima (51 frutos) com $1 \mathrm{~cm}$ de diâmetro, inteiros (fig. 06). Intestino cheio de sementes, inclusive de Byrsonima; Nematódeos freqüentes: pedacos de cotilédone.

N. 30. Fêmea II. Dados biométricos. Peso: $3,580 \mathrm{~kg}$; comprimento total: $50,0 \mathrm{~cm}$; comprimento do esôfago: $3,6 \mathrm{~cm}$; comprimento do estômago: $16,8 \mathrm{~cm}$; comprimento do intestino: $130,0 \mathrm{~cm}$.

Estômago cheio ( $24 \mathrm{~g}$ ) de pedaços de cotilédones e caroço de "tucum". Intestino cheio de fragmentos de crustáceos, pedaços de caule e de folha; algas freqüentes.

No 31. Fêmea II. Dados biométricos. Peso: $3,750 \mathrm{~kg}$; comprimento total: 51,0 cm; comprimento do esôfago: $4,3 \mathrm{~cm}$; comprimento do estômago: $20,3 \mathrm{~cm}$; comprimento do intestino: $130,0 \mathrm{~cm}$.

Estômago completamente cheio $(90 \mathrm{~g})$ de frutos de Byrsonima, pedaços de pericarpo, de folha. Intestino cheio de caroços de Byrsonima e de material digerido.

N. 32. Fêmea II. Dados biométricos. Peso: $2.110 \mathrm{~kg}$; comprimento total: $43,5 \mathrm{~cm}$; comprimento do esôfago: $3,5 \mathrm{~cm}$; comprimento do estômago: $16,0 \mathrm{~cm}$; comprimento do intestino $105,0 \mathrm{~cm}$.

Estômago com $6 \mathrm{~g}$ de sementes de Inga, pedaços de pericarpo e de caule. Intestino cheio de sementes de Eugenia e frutos de Byrsonima, Nematódeos e algas clorófitas.

Vegetação

Em julho e outubro de 1983 e abril de 1984, realizamos estudo da vegetação nas áreas onde os espécimes de "pacu" (Collossoma mitrei) foram capturados para análise do trato alimentar. As áreas a que nos referimos pertencem aos Municípios de Barão de Melgaço e Poconé, Estado de Mato Grosso, consoante discriminação que se segue.

\section{Barão de Melgaço}

\section{Margens do Rio Cuiabá}

A vegetação ciliar praticamente não existe - foi quase totalmente destruída pela ação das numerosas famílias instaladas ao longo das margens. Percorrendo as margens, conseguimos encontrar algumas espécies vegetais relacionadas com a vida do "pacu" e outras espécies de peixe, notadamente com a alimentação, tais como:

- Vitex cymosa Bert., conhecida localmente por "tarumã" e pertence à família Verbenaceae. Árvore frondosa, porém perde a folhagem no início da floração; flor lilás, pequena, numerosas, sendo que as pétalas ligadas, formando um tubo, caem com facilidade, especialmente dentro do rio; fruto negro na maturação, oblongo, com cerca de $2 \mathrm{~cm}$ de comprimento. $\mathrm{O}$ "pacu" come os frutos e as pétalas.

- Ipomoea fistulosa Mart. ex Choisy, Convulvulaceae latescente, herbácea, conhecida por "algodão". O "pacu" e outras espécies de peixes comem as folhas.

- Pouteria torta (Mart.) Radlk, (Sapotaceae) latescente; árvore bem ramosa, com frutos e flores abundantes. Seu nome local é "parada". O "pacu" come os frutos.

- Inga sp. (Leguminosae Mim.), conhecida por "gaiuvira”; árvore alta, frondosa, bem ramosas, cujos frutos notadamente as semente com arilo servem de alimento para o "pacu" e outras espécies de peixe. No clímax da maturação se desenvolvem larvas de insetos no interior dos frutos.

- Bactris glaucescens Drude (Palmae) completamente armada. É conhecida localmente por "tucum". O "pacu" come os frutos dessa palmeira. Os pescadores usam os frutos como isca para pescar "pacu". 
Baía água limpa e área de inundação

A vegetação é densa, pouco afetada pela ação do homem. As Myrtaceae são as mais representadas. Os frutos dessa família são sempre apreciados por várias espécies de peixes, notadamente o "pacu". Mencionamos a seguir as espécies coletadas e identificadas:

-Combretum leprosum Mart. (Combretaceae), cipó bem ramoso; flores abundantes. O "pacu" come as pétalas e os estames quando caem nas águas.

- Eugenia patrisi Vahl. (Myrtaceae), conhecida por "roncador". É o gênero mais bem representado nesta área. $\mathrm{O}$ "pacu" 'come os frutos, as pétalas e os estames. ((Figura 11).

- Alchornea castaneaefolia (Wild.) Juss. ("sarã”). Sapium sp. ("sarã-de-leite”). Duas Euphorbiaceae, sendo Sapium, latescente. Alchornea castaneaefolia (Wild). Juss. ocorre sempre nas margens da baía e do rio, com muita freqüência. Queremos lembrar que, dentre outras substâncias, a proteina está sempre presente no látex, daí várias espécies de peixe utilizarem espécies laticíferas como alimento.

- Ficus gardneriana (Miq.), Ficus sp. e Pseudolmedia sp., duas Moraceae laticíferas; árvores frondosas, sendo que Ficus gardneriana é freqüente na área. O "pacu" come os frutos e as folhas dessas duas espécies. Ficus gardneriana é conhecida por "figuerinha";

- Rudgea cornifolia (H.B.K.) Standl. Rubiaceae arbustiva, da mata; fruto vermelho na maturação; freqüente.

- Ocotea sp. ((Lauraceae), árvore de porte médio; folha, fruto e casca do fuste com óleo essencial, "Louro". O "pacu” come os frutos.

- Byrsonima sp. (Malpighiaceae); arbusto da mata; fruto pequeno, amarelo na maturação. O "Pacu” come os frutos. O gênero Byrsonima é conhecido por "murici".

- Crataeva tapia L. (Capparidaceae), conhecida por "birreiro"; árvore grande, da mata; fruto globoso. Capparis sp. é outra Capparidaceae arbustiva que ocorre na área; ramos resistentes; flor alva, com numerosos estames; folha coriácea. $\mathrm{O}$ "pacu" come as pétalas e os estames.

- Celtis iguanae (Jacq.) Sarg. "upiá” e Celtis aculeata Planch. (“upiá” ou "sarã-deespinho"); Ulmaceae das margens da baía e do rio; arbusto ou árvore pequena, bem ramosa; frutos pequenos, avermelhados na maturação, apreciados pelo "pacu".

- Pistia stratioites L. (Araceae), aquática natante; ocorre formando grandes populações flutuantes, com raízes fasciculadas que servem de suporte a comunidade ficológicas.

- Ludwigia natans Ell. (Onagraceae); aquática natante; ramos longos, com raízes adventícias onde se desenvolvem várias espécies de algas.

- Polygonum acuminatum H.B.K. (Polygonaceae); aquática fixa, herbácea de até $2 \mathrm{~m}$ de altura; freqüente nas margens da baia e nos corixos.

- Genipa americana L. (jenipapo), Rubiaceae; árvore grande, ramosa, folha grande, membranácea, fruto mole na maturação. O "pacu" come os frutos quando maduros.

- Salacia elliptica (Mart.) G. Don. Hippocrateaceae, árvore de $14 \times 0,40 \mathrm{~m}$, ramosa; folha crassa; frutos de cor cinza, porém amarelos na maturação. $\mathrm{O}$ "Pacu" come as sementes com arilo. Esta espécie é conhecida por "ciputá" ou "saputá".

- Vochysia divergens Pohl; Vochysiaceae de $8 \times 0,30 \mathrm{~m}$; fuste com casca fissurada; flor amarela. É conhecida por "cambará".

\section{Baía Sinhá Mariana}

É uma das áreas mais expressivas, onde o ecossistema não sofreu agressividade humana. Esse ecossistema é representado, além da fauna aquática e terrestre, por grandes populações de plantas aquáticas, ciliares e da área inundável. Mencionamos a seguir as espécies vegetais coletadas e observadas:

- Pontederia rotundifolia L. (Pontederiaceae); aquática, abundante, com ramos longos, dotados de raízes fasciculadas adventícias onde se desenvolvem populações de algas. 
Eichhornia crassipes (Mart.) Solms. (Pontederiaceae); flutuante, abundante, com numerosas raizes fasciculadas onde se desenvolvem populações de microartrópodes e de algas.

- Eichhornia azurea (Sw.) Kunth., (Pontederiaceae), aquática flutuante ou fixa. Ocorre formando grandes populações. área.

- Reussia subovata (Seub.) Solms (Pontederiaceae) flutuante, também ocorre nesta

- Cissus spinosa Camb. (Vitaceae), cipó com espinho; fruto pequeno, globoso; inflorescência vermelha; freqüente. "taiuá". O "Pacu" come os frutos.

- Psidium acutangulum Dc. (Myrtaceae); Nas margens; arbusto com frutos subglobosos. "gaiabinha". O "Pacu" come os frutos.

- Couepia cataractae Ducke (Chrysobalanaceae); árvore ou arbusto das margens, bem ramosa; folha coriácea, esbranquiçada na face inferior; estames numerosos; "pimenteira".

- Paspalum repens Berg. (Gramineae); aquática fixa com ramos longos flutuantes, dotados de raízes fasciculadas adventícias. Ocorrem com freqüência.

- Alchornea castaneaefolia (Wild.) Juss. Polygonum acuminatum H.B.K. Eugenia patrisii (roncador), Ficus gardneriana (Miq.) Miq., Spondias lutea L. (Anacardiaceae), cujos frutos são apreciados por várias espécies de peixe; "cajá", Celtis aculeata, Pistia stratioites L., Ludwigia natans Ell. e Salvinia sp.

\section{Baía do Mato do Rio Pirai}

Vegetação densa, ecossistema inalterado. Espécies coletadas e observadas nesta Baía:

- Attalea phalerata Mart. (“acuri”), Palmae de fruto elíptico ou oblongo; cada cacho contém centenas de frutos; freqüentes na área.

- Cecropia sp. (“Imbaúba”), Moraceae de frutos longos e finos. Várias espécies de peixe comem os frutos dessa espécie. Apreciados também por pássaros.

- Rheedia brasiliensis (Mart.) Pl. (Guttiferae), árvore pequena, ramosa; frutos pequenos, amarelos na maturação. O "pacu" come os frutos.

- Duroia duckei Huber ex Char. (Rubiaceae); árvore pequena ou arbusto; folha coriácea. É conhecida por "mamelada". O "Pacu" come os frutos.

- Cassia fistula L., Inga sp.,Alchornea castaneaefolia, Rudgea cornifolia, Cissus spinosa, Reussia subovata, Eichhornia azurea, Pontederia rotundifolia, Goupia sp. e Aptandra tubicina (Poepp.) Benth. ex Miers Eugenia patrisii Vahl.

\section{Porto Jofre, Município de Poconé}

No período entre 10 e 14 de abril de 1984, continuamos os trabalhos de coleta de plantas nas áreas onde os espécimes de "pacu" foram capturados para estudo biométrico e do trato alimentar existente no aparelho digestivo.

Percorrendo as margens do rio Cuiabá, constatamos que a vegetação ciliar é bastante densa e pouco afetada pela ação do homem, exceto nas partes onde há fazendas com atividades agropecuárias. Na oportunidade foram coletadas nas margens do rio Cuiabá as espécies que se seguem:

Pouteria glomerata (Miq.) Radlk. Sapotaceae, arbórea ou arbustiva, bem ramosa, latescente; fruto subgloboso, de sabor muito azedo, notadamente antes da maturação, muito apreciado pelo "pacu"; é usada também como isca e conhecida por "laranjinha".

Byrsonima sp., Malpighiaceae, arbustiva ou arbórea pequena, ramosa; frutos abundantes, globosos, com cerca de $1 \mathrm{~cm}$ de diâmetro, vermelhos na maturação, muito apreciados por várias espécies de peixe da Região, inclusive "pacu". Conhecidos por "laranjinha ou murici" e usados como isca (coleta 1749).

- Nectandra sp. Lauraceae, árvore com $8 \times 0,30 \mathrm{~m}$; folha e casca do fuste com óleo 
essencial; flor pequena, de cor bege.

Paullinia pinata L. Sapindaceae, trepadeira com gavinhas; fruto vermelho na maturação; semente com arilo, muito apreciada pelo "pacu" (coleta 1759).

Inga uruguensis $\mathrm{H}$. \& A. Leguminosae, árvore bem ramosa, 7x0,35m; frutos longos, comestíveis; sementes com arilo. $\mathrm{O}$ "pacu" e outras espécies de peixe comem as sementes. No clímax da maturação, sempre desenvolvem larvas de insetos. Esta espécie é conhecida por "ingá”" (coleta 1760).

- Panicum dichotomiflorum Michx. (= P. chloroticum Nees) Gramineae, fixa, com ramos longos, flutuantes; folhas estreitas; caule moderadamente fino, com raizes adventícias, nas quais se desenvolvem fito e zooplancton; forrageira, apreciada pelo gado bovino e "capivara"; ocorre formando grandes populações (número de coleta 1744).

Panicum elephantipes Nees. Gramineae, aquática, fixa com ramos longos, grossos, fistulosos, às vezes parcialmente ocos, os quais servem de suportes e fitoplâncton e zooplâncton; folhas longas; ocorre formando grandes populações; forrageira para gado bovino e "capivara" (coleta número 1745).

Eugenia patrisii Valh., Myrtaceae, arbusto ou árvore pequena, bem ramosa; frutos abundantes, pequenos, quase roxos na maturação; o "pacu" come os frutos "roncador", (coleta 1761).

Eugenia sp., Myrtaceae, árvore de até $6 \mathrm{~m}$ de altura, bem ramosa; frutos abundantes, bem maiores que os da espécie anterior, amarelos na maturação; o "pacu" come os frutos; freqüente na área.

Alchornea castaneaefolia, Vochysia divergens, Spondias lutea, Ficus sp., Ficus gardneriana, Genipa americana, Cecropia sp, Eichhornia azurea, Pontederia rotundifolia, Bactris glaucescens, Cissus spinosa, Ipomoea fistulosa, citadas anteriormente.

Espécies coletadas na Baía do Pequeri — área inundada

- Vigna adenanthera (G.F.N.) M.M. \& S. Leguminosae, trepadeira sem gavinha; folha fina; fruto cilíndrico, fino, negro na maturação; sementes minúsculas; várias espécies de peixe, inclusive o "pacu", comem os frutos e sementes. Essa espécie ocorre formando grandes populações (n. de coleta 1758).

- Cabomba aquatica Aublet, Nymphaeaceae, submersa, com numerosos ramos, nos quais se desenvolvem colônias de algas; folhas filiformes; os ramos são apreciados por várias espécies de peixe. ( $\mathrm{n}^{\circ}$ de coleta 1748 ).

- Nymphaea sp., aquática, fixa, com folhas flutuantes, dotadas de pecíolo longo. O "pacu" e outras espécies de peixe comem as folhas e pétalas do botão floral.

- Reussia subovata (Seub.) Solm. Laubach., Pontederiaceae, aquática, fixa, com ramos flutuantes; flor alva com pontos amarelos, sempre visitadas por insetos, especialmente abelhas (Figura 39).

- Mikania congesta, Compositae, herbácea, prostrada sobre outras espécies; folha fina; ocorre formando populações; o "pacu" come as folhas (1754).

- Caperonia castaneaefolia (L.) St. Hil. Euphorbiaceae, herbácea, aquática, fixa, emergente; caule parcialmente oco; flor alva, minúscula, fruto tricoca.

- Psittacanthus cordatus Blu. Loranthaceae, coletada sobre uma leguminosa; folha mais ou menos carnosa; flor vermelha; fruto negro na maturação; o "pacu" come os frutos; freqüente na área. (1737).

- Pontederia cordata L. var. lanceolata, Pontederiaceae, fixa, ou livre; ocorre formando grandes populações, entre as quais vivem várias espécies de insetos.

- Ipomoea sp., Convolvulaceae, trepadeira latescente; folha fina; flor grande, lilás; ocorre formando grandes populações; o "pacu" come as folhas.

- Eichinodorus paniculatus Micheli, Alismataceae, aquática, fixa; pétalas alvas; o "pacu" come as pétalas e as folhas dessa espécie. 
- Sarcostemma clausum (Jacq.) Roem. etc Schult. (= Funastrum clausum (Jacq.) Schetr. Asclepiadaceae, latescente, látex copioso, trepadeira com numerosos ramos finos; folha pequena; flor alva; freqüente na área; o "pacu" come as flores (1743).

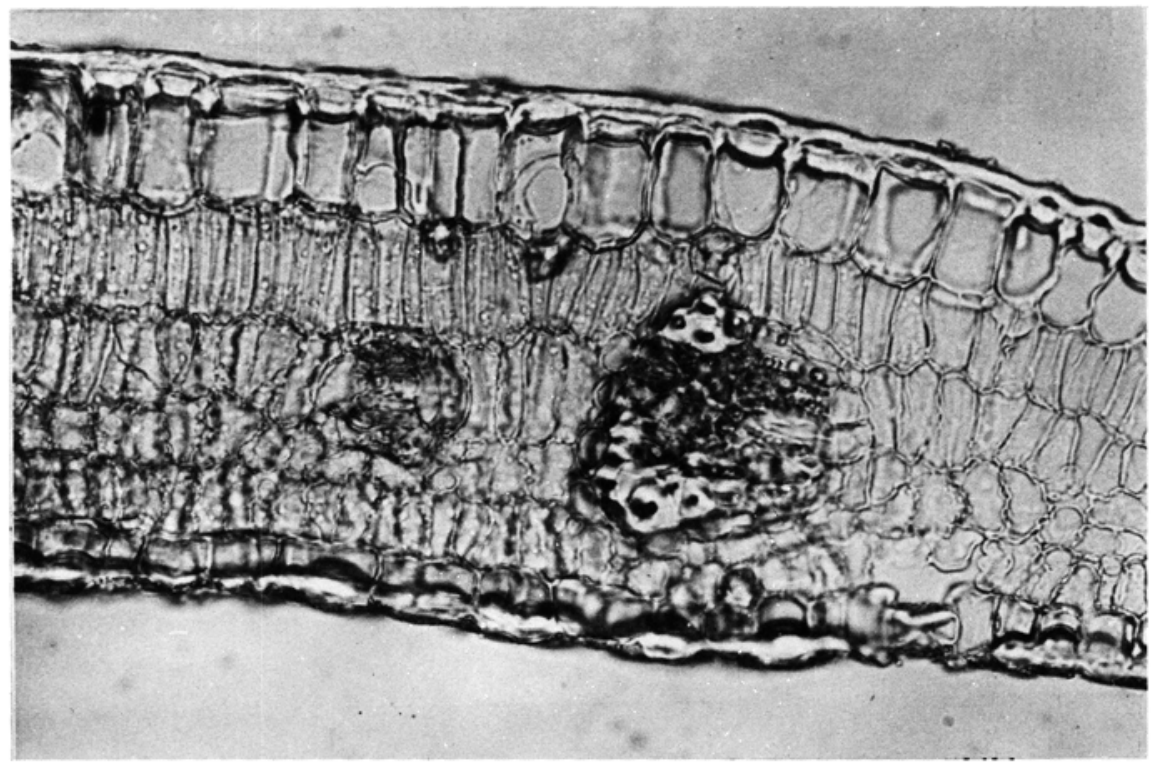

Figura 1 - Corte transversal de um foliolo de Leguminosae (48x).

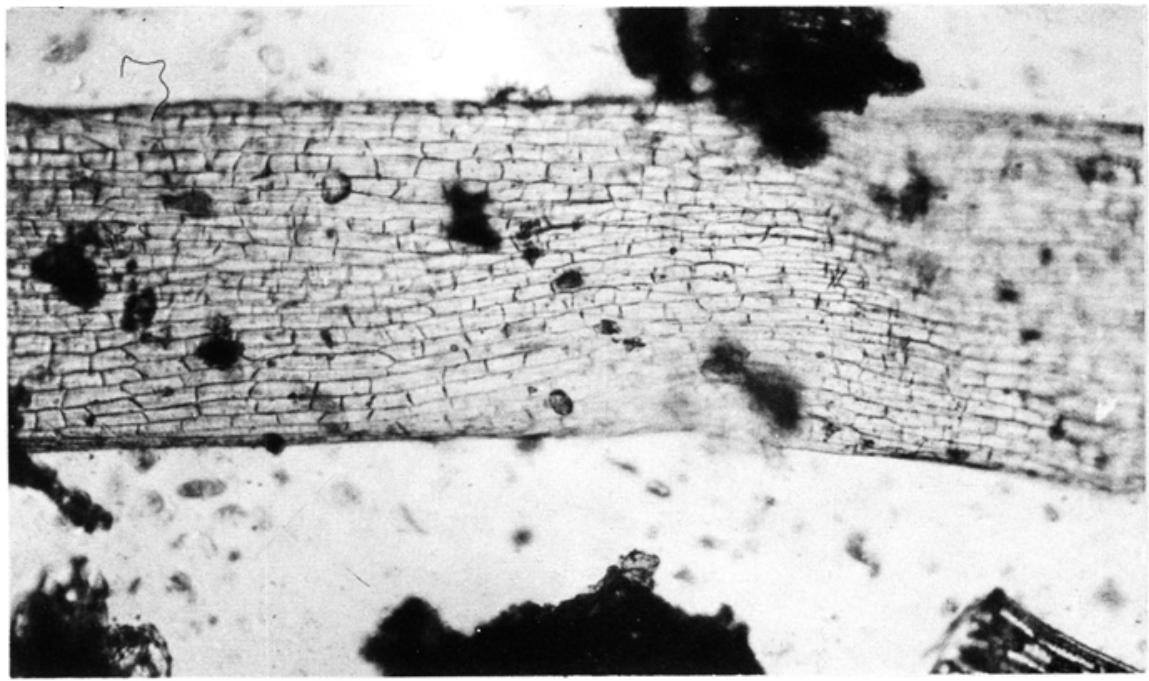

Figura 2 - Pedaço de caule de dicotiledônea ((25x) 


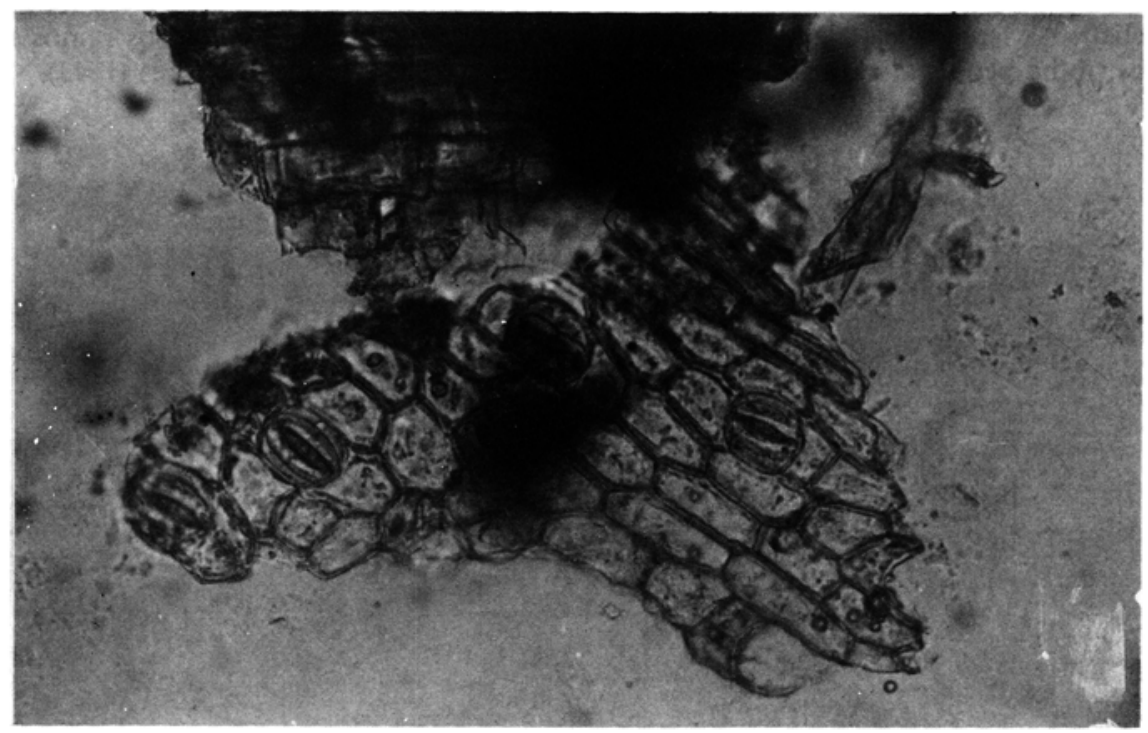

Figura 3 - Epiderme abaxial de folha de dicotiledônea (48x)

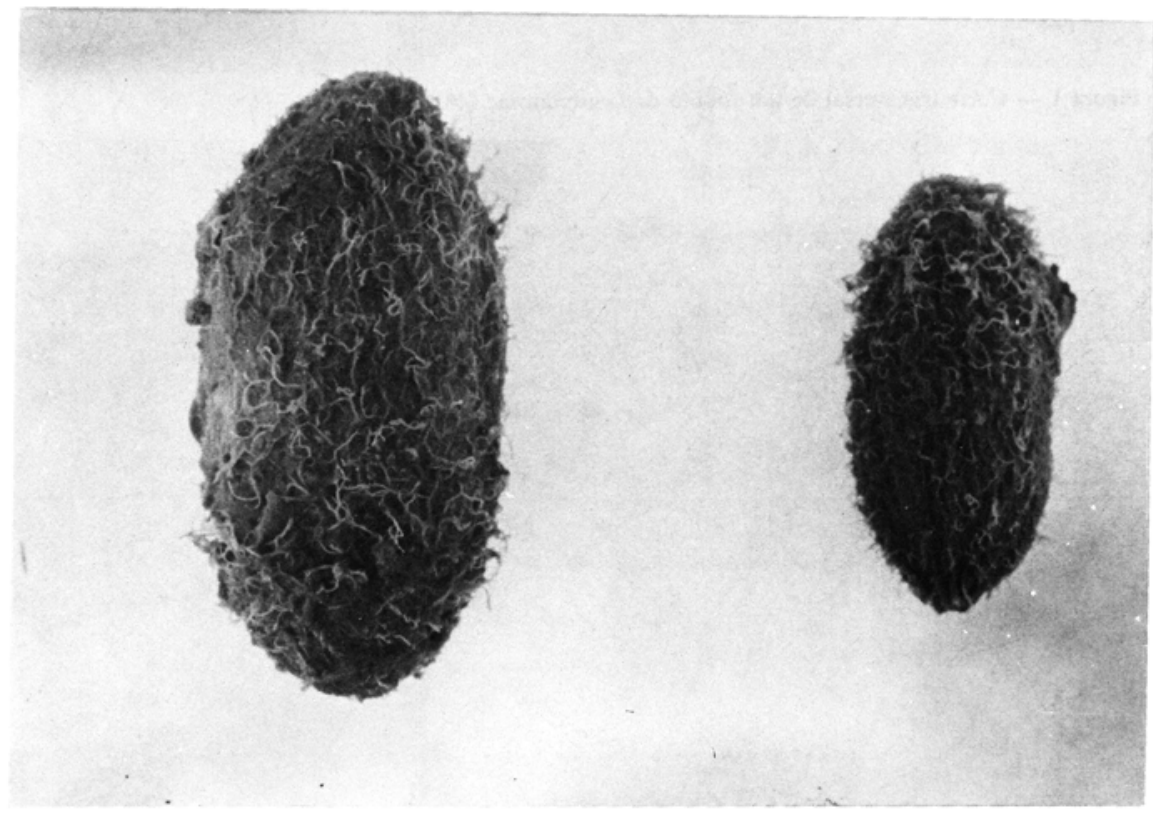

Figura 4 - Caroços de Spondias lutea (cajá). 2x 


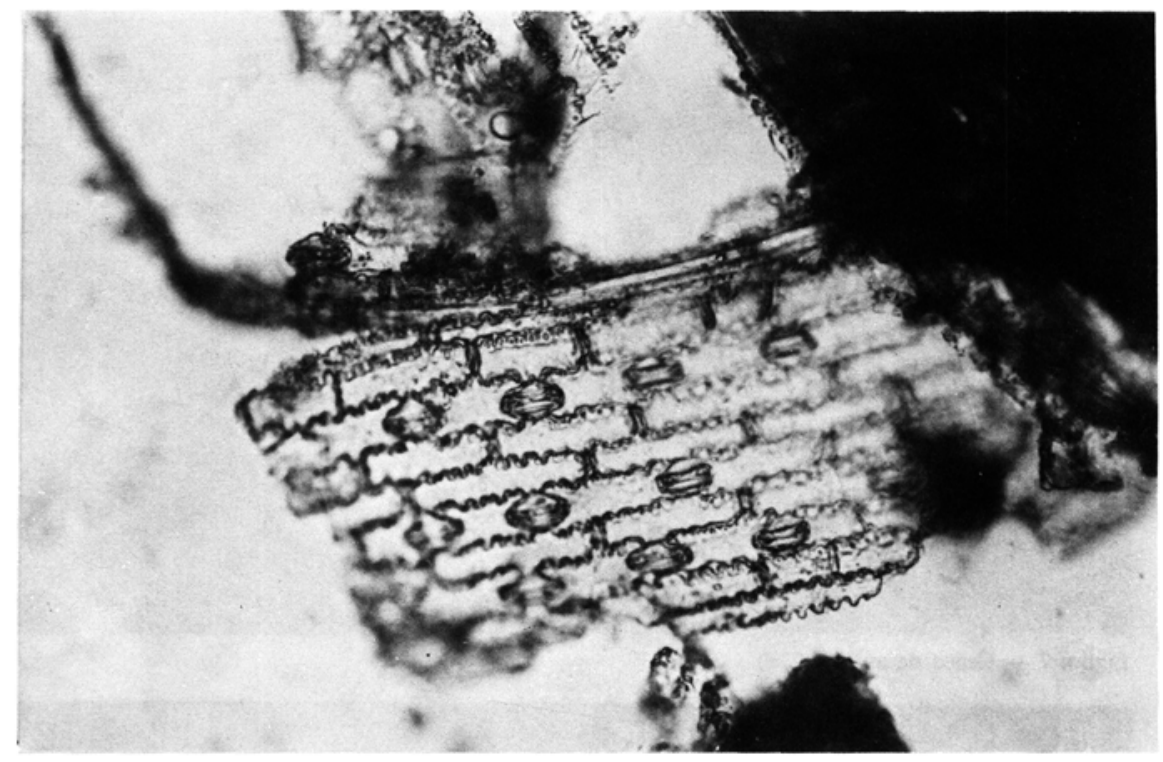

Figura 5 - Epiderme abaxial de folha de gramínea (58x)

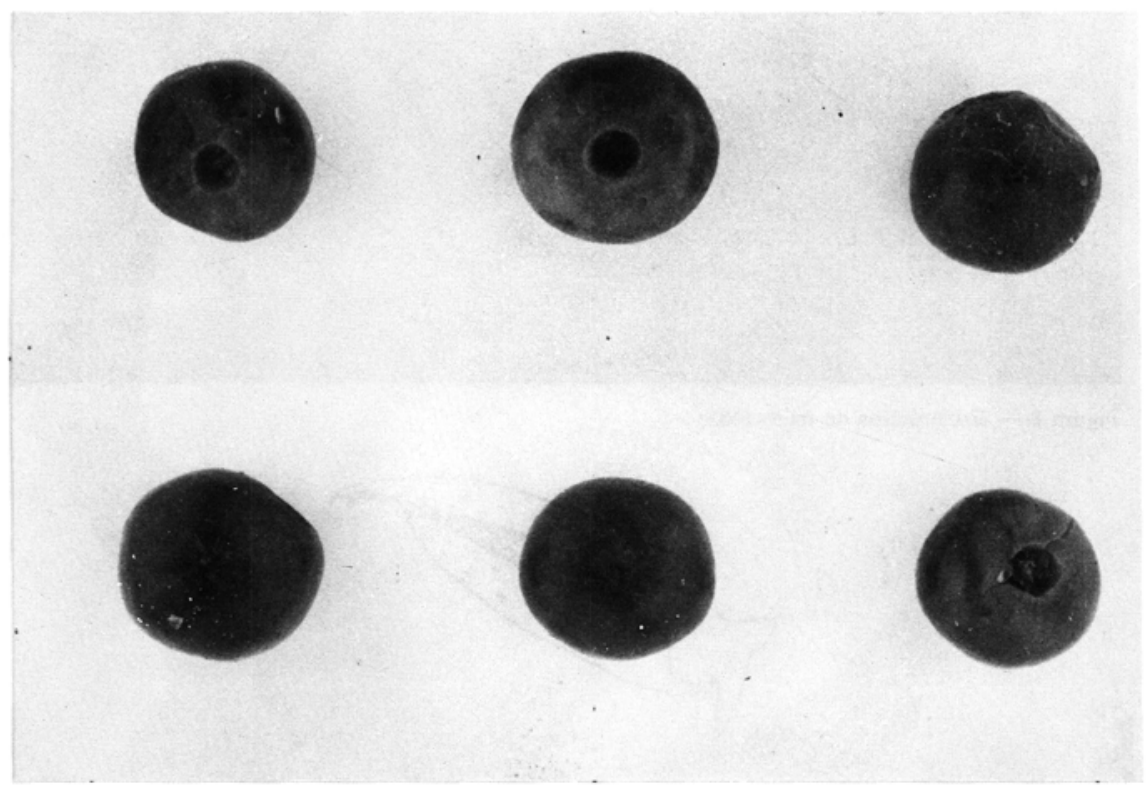

Figura 6 - Frutos de Byrsonima sp. (2x) 


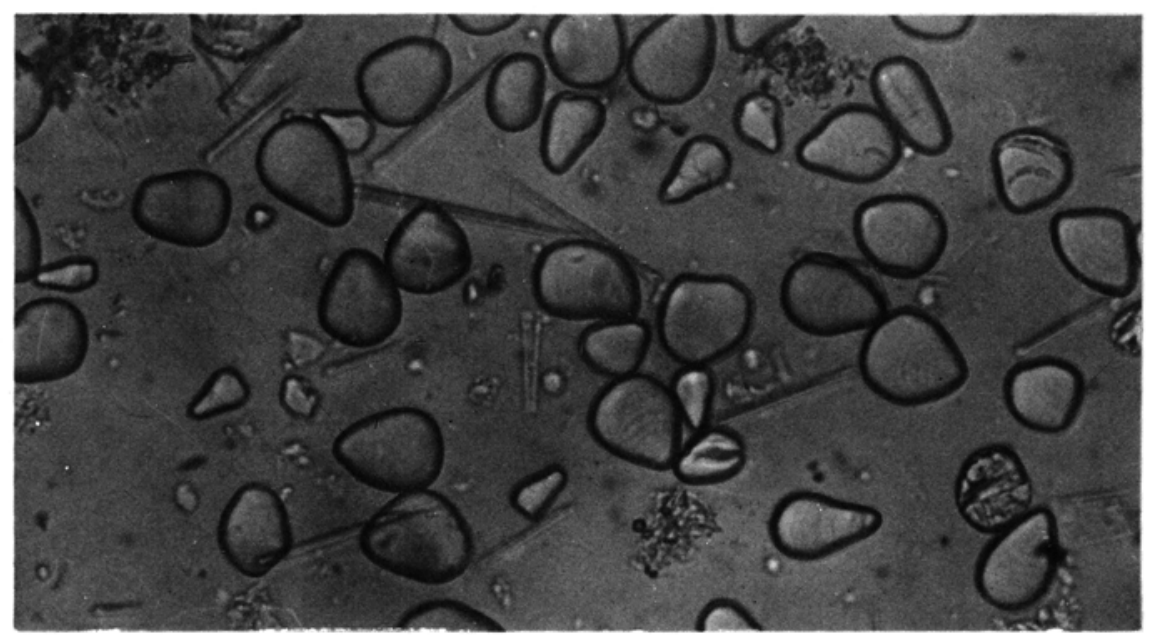

Figura 7 - Grãos de amido (72x)

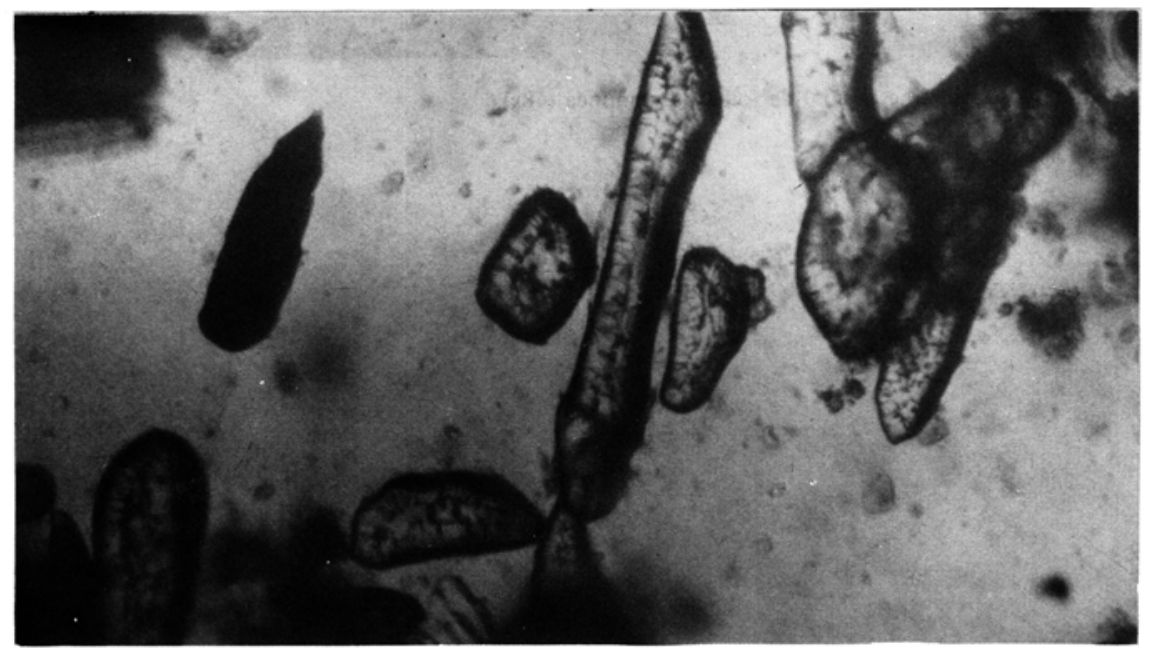

Figura 8 - Esclerócitos de fruto (48x)

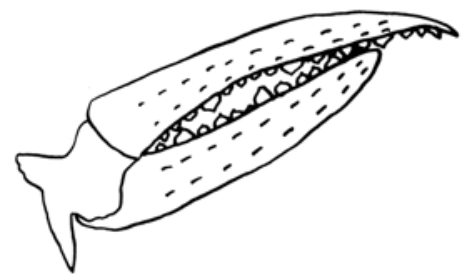

Figura 9 - Pata de crustáceo, "caranguejo do Pantanal" 


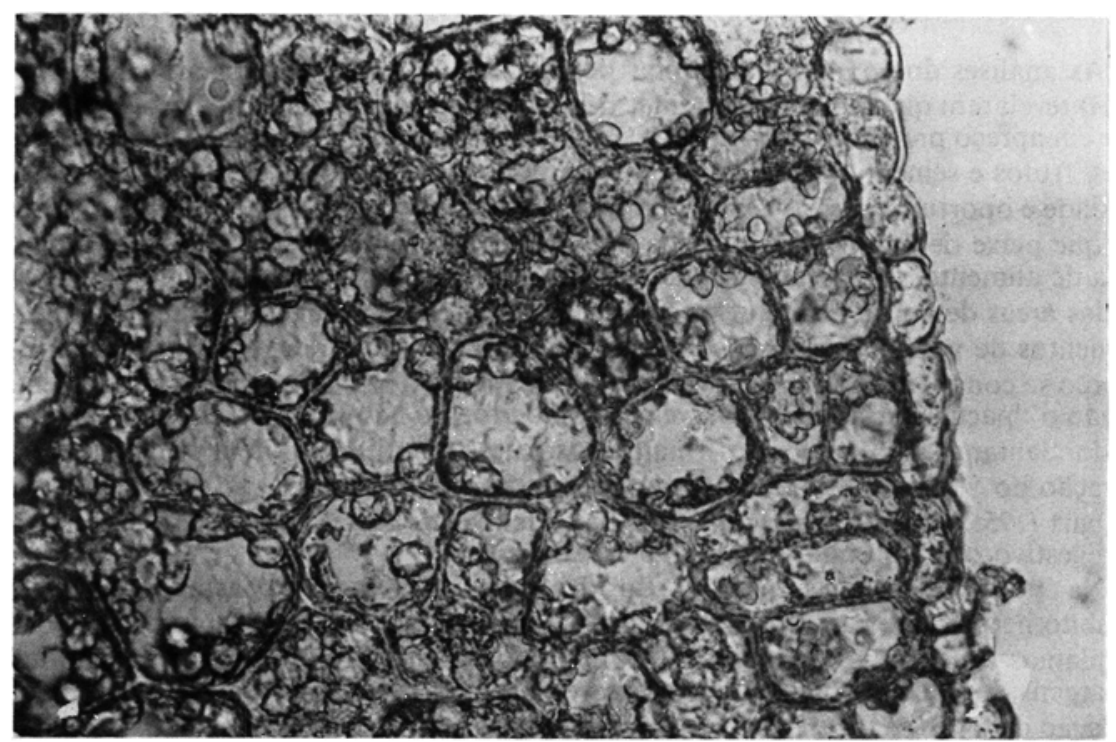

Figura 10 - Corte transversal de cotilédone, mostrando grãos de amido (48x)

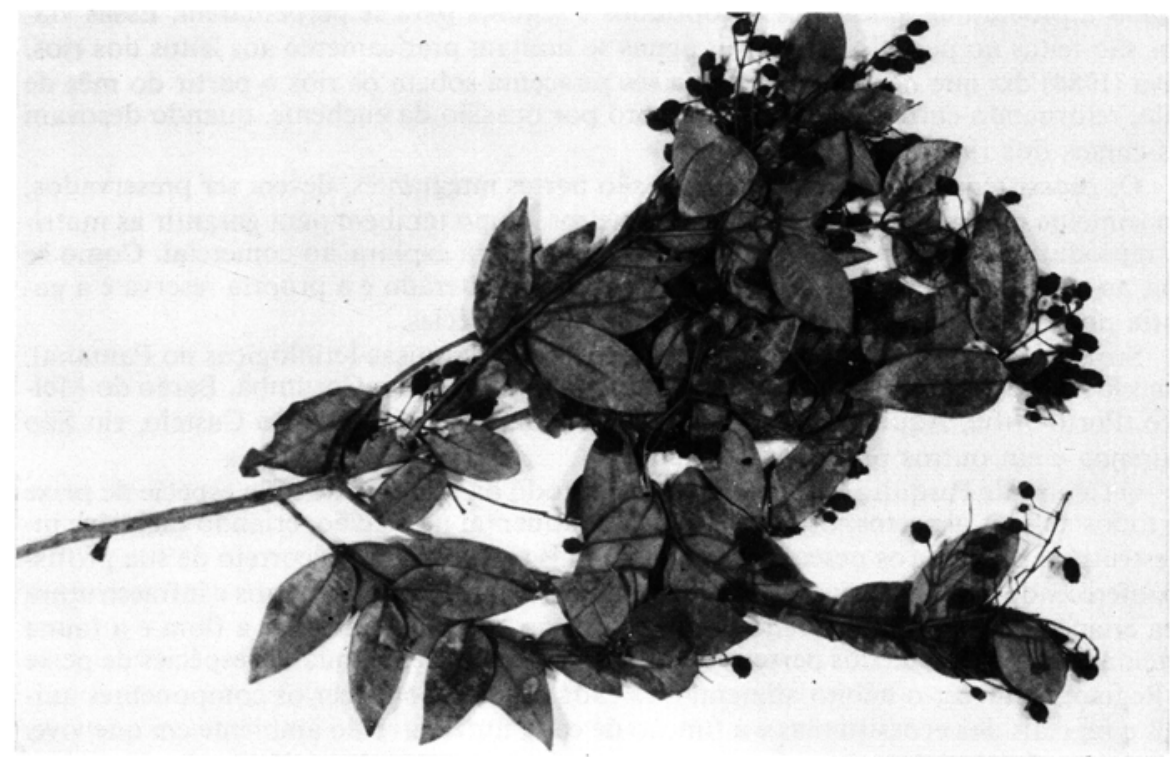

Figura 11 - Ramos frutíferos de Eugenia patrisii. 


\section{Comentários}

As análises do conteúdo alimentar do aparelho digestivo do "pacu" (Colossoma mitrei) revelaram que o hábito alimentar dessa espécie é marcadamente herbívoro. A espécie em apreço prefere como alimento plantas superiores, especialmente folhas, caules, flores, frutos e sementes de dicotiledôneas e monocotiledôneas. Contudo, havendo necessidade e oportunidade, o "pacu" também utiliza-se de crustáceos e insetos. Acreditamos que peixe de hábito herbívoro deve gastar pouca energia durante a pastagem em busca de alimento, em virtude de encontrá-lo com mais facilidade, desde que a vegetação das áreas de ocorrência da espécie fitófaga não esteja destruída. A abundância de fragmentos de vegetais inalterados no intestino do "pacu" indica que, seguramente, a digestão se completa nesta parte do aparelho digestivo. Resta saber se este fato se repete quando o "pacu" é criado em "cativeiro" com alimento natural, ou artificialmente preparado. Santana-Honda (1974) afirma que os frutos constituem o item principal na alimentação do "tambaqui" (Colossoma bidens) (Spix). Por outro lado, Moraes Filho \& Schubart (1955) observaram quantidade considerável de fragmentos vegetais no aparelho digestivo do "dourado" (Salminus maxillosus).

$\mathrm{Na}$ época das cheias, aumentam consideravelmente as áreas de pastagem dos peixes de hábito herbívoro e carnívoro, notadamente para os que se alimentam de artrópodos e de plantas superiores, enquanto que no período de estiagem, as pastagens se limitam às margens dos rios, lagos, lagoas, corixos e baías, daí a necessidade de se preservar a vegetação de todas as margens e das áreas inundáveis. Se os ecossistemas são destruídos, fatalmente ocorrerá migração, com efeito diminuirá o estoque natural pesqueiro e, conseqüentemente, um problema social será inevitável.

Os espécimes machos e fêmeas de "pacu", capturados na época da inundação (mês de abril), em Porto Jofre, apresentavam muita gordura (substância de reșerva) e o aparelho reprodutor em estágio bem adiantado (I, II e III). No período de inundações há abundância de alimentos para os peixes, especialmente frutos e sementes. Nessa época, os peixes, inclusive o "pacu", acumulam bastante energia, suficiente para realizar longas viagens à procura de ambientes apropriados e seguros para se perpetuarem. Essas viagens são feitas no período em que as águas se limitam praticamente aos leitos dos rios. Paiva (1984) diz que no Pantanal os peixes piracema sobem os rios a partir do mês de maio, retornando entre outubro e novembro por ocasião da enchente, quando desovam nos cursos dos rios.

Os ecossistemas, dos quais os peixes são partes integrantes, devem ser preservados, não somente para manter os estoques pesqueiros, como também para garantir as matrizes reprodutoras das espécies criadas em cativeiro para exploração comercial. Como se sabe, as matrizes são sempre renovadas. O habitat inalterado é a própria reserva e a garantia por excelência do patrimônio genético das espécies.

Sugerimos, também, a criação de um Centro de Pesquisas Ictiológicas no Pantanal, com sede em Corumbá. Esse centro instalaria laboratórios em Corumbá, Barão do Melgaço, Porto Jofre, Aquidauana, Acurizal, Miranda, Cáceres, Baía do Castelo, rio São Lourenço e em outros pontos apropriados.

O Centro de Pesquisa teria por escopo o estudo da biologia de cada espécie de peixe em todos os seus aspectos; orientar a pesca continental na Região, criando inclusive infraestrutura; preparar os pescadores profissionais para o exercício correto de sua profissão, of erecendo-lhes, inclusive, noções de ecologia; estabelecer parâmetros e infraestrutura para criação de peixe em cativeiro para exploração comercial; estudar a flora e a fauna relacionadas com a vida dos peixes; identificar cientificamente todas as espécies de peixe da Região; conhecer o hábito alimentar de cada espécie; conhecer os componentes animais e vegetais dos ecossistemas e a função de cada um dentro do ambiente em que vive. Com isso, a Instituição ocuparia espaço, assumindo o controle ecológico do Pantanal. 
A partir daí, estaria formada a base para se explorar, sob plano de manejo natural sustentado, os recursos renováveis do Pantanal, sem causar desajustes irreparáveis aos ecossistemas.

Espécies vegetais apreciados pelo "pacu" como alimento: Vitex cymosa Cham. (tarumã), Eugenia patrisii Vahl. (roncador), Eugenia sp, Alchornea castaneaefolia (Wild.) Juss. (Sarã), Neptunia prostrata, Sapium sp. ((sarã-de-leite), Mikania congesta, Ficus gardneriana (Miq.) Miq. (figueirinha), Ocotea sp. (louro), Crateava tapia L. (birreiro), Byrsonima sp. ((murici), Celtis iguaneae ((Jacq.) Sarg. (upiá), Celtis aculeata Planch. (Upiá ou sarã-de-espinho), Genipa americana L. (jenipapo), Sallacia elliptica (Mart.) G. Don (ciputá ou saputá), Cissus spinosa Camb. (taiuá), Psidium acutangulum DC; (goiabinha), Ipomoea fistulosa Mart. ex. Choisy (algodão), Pouteria rorta, Bactris glaucescens Drude (tucum), Inga uruguensis, Rheedia brasiliensis (Mart.) Pl., Combretum leprosum Mart., Phthirusa sp., Paullinia pinata, Ipomoea, sp., Echinodorus paniculatus, Mikania sp., Sarcostemma clausum, Nymphaea sp., Pouteria glomerata e Spondias lutea (cajá).

Gottsberg (1978) apresenta uma lista de espécies vegetais que são dispersadas por peixes, em Humaitá, Amazônia, através de ingestão de sementes como alimento, especialmente das famílias Moraceae, Annonaceae, Sapotaceae, Myristicaceae, Elaeocarpaceae, Chrysobalanaceae Burseraceae, Araceae e Simaroubaceae. Diz ainda que, em Humaitá, durante as inundações das matas de várzeas e igapó, os peixes dos rios e igarapés se espalham por toda vegetação parcialmente inundada e se alimentam, entre outros, de frutos e sementes caídos na água.

As fotomicrografias, constantes deste trabalho, ilustram e comprovam o tipo de alimento utilizado pelo "pacu". As concreções silicosas são freqüentes em várias espécies de gramíneas e drusas e ráfides de oxalato de cálcio são igualmente freqüentes em muitas espécies de dicotiledôneas e monocotiledôneas. Esses elementos foram detectados com freqüência no aparelho digestivo do "pacu".

Como já salientamos no capítulo de resultados, várias espécies vegetais latescentes são usadas por certas espécies de peixe como alimento, notadamente o “pacu”. Essa preferência tem tazão de ser, pois, no látex, dentre outras substâncias está presente a proteína. Seria oportuno cogitar-se em incluir na ração de peixes criados em cativeiro para exploração comercial plantas latescentes, evidentemente com o cuidado de não incluir plantas laticíferas tóxicas. Como por exemplo, citamos Convolvulaceae (Ipomoea sp, Ipomoea cornea var. fistulosa) Euphorbiaceae, Sapotaceae, Apocynaceae, Moraceae e algumas Leguminosae (Minosa laticifera Rizz. \& Mattos, M. rixosa Mart. M. Caesalpiniaefolia Benth.), como plantas produtoras de látex. Por outro lado, Lemnaceae (Lemna, Spirodela, Wolfia e Wolffiella) é rica em proteína, glóbulos lipídicos e grãos de amido e Commelinaceae (Commeelina, Tradescantia e Zebrina são igualmente ricas em proteína. Esses grupos de plantas devem ser estudados, visando o seu aproveitamento na alimentação de peixe.

Neptunia prostata (Lam.) Baill. e Mimosa pudica L. (Calumbi) são Leguminosae, cujas folhas e flores são apreciadas por "pacu" e "cará", como alimento. As folhas dessas duas espécies respondem aos estímulos externos (os folíolos se fecham quando qualquer objeto toca-os). Esse movimento natural é realizado pela proteína contráctil (actina) existente nas folhas das espécies referidas. A presença dessa proteína justifica a preferência por parte de algumas espécies de peixe. 


\section{Referências Bibliográficas}

BARD, J,: KIMPE, P. de; LEMASSON, J. \& LESSENT, P. 1974. Manual de piscicultura para a América e África Tropicais. Trad. Antonio M. dos Santos \& F.V. Cruz. França, Nogent-Sur-Marne, 328p. il.

GOTTSBERGER, F. 1978. Seed dispersal by fish in the inundated regions de Humaitá, Amazônia. Biotropica, 10(3):170-183, il.

JANSEN, W. A. 1962. Botanical histochemistry. London, Ed. W.H., 408p. il.

MACHADO, C.E.M. 1974. Criação prática de peixes. São Paulo, Nobel, 112p., il.

MORAES FILHO, M.B. \& SCHUBART. O. 1955. Contribuição ao estudo do Dourado. São Paulo, 131p. il.

PAIVA, M.P. 1984. Aproveitamento de recursos faunísticos do Pantanal do Mato Grosso: Pesquisas necessárias e desenvolvimento de sistemas de produção mais adequados à região. Brasília, EMBRAPA, 71p., il.

PAULA, J.E. de 1976. Observação sobre plantas aquáticas relacionadas com a vida dos peixes da bacia do rio Itapecuru. Recife. SUDENE/GEOTÉCNICA, II + 77p. il.

PAULA, J.E. de 1978. Estudos sobre a vegetação aquática e ciliar relacionada com a vida dos peixes dos rios Araguaia e Tocantins. Brasília, SUDEPE, 78p., il.

PAULA, J.E. de; DORNELLES, L.D.C. \& ALBUQUERQUE, J.S.L. 1982. Estudo da vegetação aquática e ciliar da bacia do Lago Paranoá de Brasília, relacionada com a vida da ictiofauna. Bol. Téc. IBDF, Brasília, 7:39-55, 55 fig.

RIBEIRO, L.P.; BERNARDINO, G.; MENDONÇA, J.O.J.; ALCÂNTARA, R.C.G.; FERREIRA, V.A. \& FIJAN, N. 19866. Ovulação induzida do pacu (Colossoma mitrei), com hormônio liberado de gonadotropina. SIMPÓSIO BRASILEIRO DE AQÜICULTURA, 4. Cuiabá, ABRAQ, p. 66.

SANTANA HONDA, E.M. 1974. Contribuição ao conhecimento da biologia de peixes do Amazonas II - Alimentação de tambaqui, Colossoma bidens (Spix). Acta Amazon., Manaus, 4(2):47-53, il.

SOUZA, J.R. 1971 Uma contribuição para o desenvolvimento da piscicultura. Viçosa, Imprensa Universitáriaa, 57p., il.

SOUZA, J.A. \& CANTELMO, O.A. 1986. Contribuição da alimentação do pacu (Colossoma mitrei, Berg 1895). Uso de abóbora (Cucurbita maxima), mandioca (Manihot esculenta) e milho (Zea mays), na alimentação do pacu. SIMPÓSIO BRASILEIRO DE AQÜICULTURA, 4. Cuiabá, ABRAQ, p. 39.

TEODORO, A.J. \& LIMA, J.A.F. Requisitos para a obtenção de reprodução espontânea do pacu (Colossoma mitrei), em cativeiro. SIMPÓSITO BRASILEIRO DE AQÜICULTURA, Cuiabá, ABRAQ, 4. p. 67. 